\title{
Controls on dissolved organic matter (DOM) degradation in a headwater stream: the influence of photochemical and hydrological conditions in determining light-limitation or substrate-limitation of photo-degradation
}

\author{
R. M. Cory ${ }^{1}$, K. H. Harrold ${ }^{1}$, B.T. Neilson ${ }^{2}$, and G. W. Kling ${ }^{3}$ \\ ${ }^{1}$ University of Michigan, Earth \& Environmental Sciences, Ann Arbor, Michigan, USA \\ ${ }^{2}$ Utah State University, Civil and Environmental Engineering, Utah Water Research Laboratory, Logan, Utah, USA \\ ${ }^{3}$ University of Michigan, Department of Ecology \& Evolutionary Biology, Ann Arbor, Michigan, USA
}

Correspondence to: R. M. Cory (rmcory@umich.edu)

Received: 1 June 2015 - Published in Biogeosciences Discuss.: 1 July 2015

Revised: 28 October 2015 - Accepted: 1 November 2015 - Published: 24 November 2015

\begin{abstract}
We investigated how absorption of sunlight by chromophoric dissolved organic matter (CDOM) controls the degradation and export of DOM from Imnavait Creek, a beaded stream in the Alaskan Arctic. We measured concentrations of dissolved organic carbon (DOC), as well as concentrations and characteristics of CDOM and fluorescent dissolved organic matter (FDOM), during ice-free periods of 2011-2012 in the pools of Imnavait Creek and in soil waters draining to the creek. Spatial and temporal patterns in CDOM and FDOM in Imnavait Creek were analyzed in conjunction with measures of DOM degradation by sunlight and bacteria and assessments of hydrologic residence times and in situ UV exposure. CDOM was the dominant light attenuating constituent in the UV and visible portion of the solar spectrum, with high attenuation coefficients ranging from $86 \pm 12 \mathrm{~m}^{-1}$ at $305 \mathrm{~nm}$ to $3 \pm 1 \mathrm{~m}^{-1}$ in the photosynthetically active region (PAR). High rates of light absorption and thus light attenuation by CDOM contributed to thermal stratification in the majority of pools in Imnavait Creek under low-flow conditions. In turn, thermal stratification increased the residence time of water and DOM, and resulted in a separation of water masses distinguished by contrasting UV exposure (i.e., UV attenuation by CDOM with depth resulted in bottom waters receiving less UV than surface waters). When the pools in Imnavait Creek were stratified, DOM in the pool bottom water closely resembled soil water DOM in character, while the concentration and character of DOM in surface water was reproduced by experimental photo-degradation of
\end{abstract}

bottom water. These results, in combination with water column rates of DOM degradation by sunlight and bacteria, suggest that photo-degradation is the dominant process controlling DOM fate and export in Imnavait Creek. A conceptual model is presented showing how CDOM amount and lability interact with incident UV light and water residence time to determine whether photo-degradation is "light-limited" or "substrate-limited". We suggest that degradation of DOM in CDOM-rich streams or ponds similar to Imnavait is typically light-limited under most flow conditions. Thus, export of DOM from this stream will be less under conditions that increase the light available for DOM photo-degradation (i.e., low flows, sunny days).

\section{Introduction}

The decomposition of dissolved organic matter (DOM) to $\mathrm{CO}_{2}$ and its subsequent transport to and release from surface waters is an important process in the carbon cycling of inland waters (e.g., Cole et al., 1994, 2007; Kling et al., 1991). This decomposition has been mainly attributed to bacterial respiration in the water column and sediments (e.g., Battin et al., 2009; Cole et al., 2007; Wetzel, 2001). Exposure to ultraviolet (UV) light is also a key control on the photochemical conversion of DOM to $\mathrm{CO}_{2}$ in surface waters (e.g., Cory et al., 2007; Moran et al., 2000; Vähätalo and Wetzel, 
2008), and coupled photochemical and microbial processing can enhance DOM degradation beyond the effect of bacteria or light alone (Cory et al., 2013; Judd et al., 2007; Tranvik and Bertilsson, 2001).

Recent work demonstrated that in shallow arctic lakes and streams the photo-degradation of DOM can greatly exceed bacterial respiration, accounting for up to $94 \%$ of the total DOM processed in the water column (Cory et al., 2014). The water column rate of DOM photo-degradation to $\mathrm{CO}_{2}$ (photo-mineralization) or to partially degraded DOM (e.g., photo-stimulated bacterial respiration; Cory et al., 2013) depends on (1) the amount of UV radiation from sunlight reaching the water surface, (2) the absorption of UV light by chromophoric DOM (CDOM), and (3) the apparent quantum yield, a term quantifying the lability of DOM as moles of product formed per moles of photons absorbed by DOM. Water column rates of DOM photo-degradation increase linearly with increasing UV light reaching the water surface, or with increasing photo-lability of DOM. However, the rate of DOM photo-degradation in the water column depends nonlinearly on CDOM concentrations and depth due to attenuation of light mainly by CDOM with depth in the water column (Hu et al., 2002; Miller, 1998).

As CDOM concentrations increase, the depth of UV light penetration decreases to shallower depths, but the average rate of light absorption by CDOM increases in the water column (Hu et al., 2002). Thus, while the depth of UV light penetration is low, on the order of 10 to $100 \mathrm{~cm}$ in the streams and small ponds in the Arctic characterized by high concentrations of CDOM (Cory et al., 2007, 2014; Gareis et al., 2010; Prairie et al., 2009; Watanabe et al., 2011), the rate of light absorption by CDOM may be high. If the light absorption rate is high enough, photo-degradation rates of DOM reach an asymptote such that increasing CDOM has no effect on photo-degradation integrated through the water column (Hu et al., 2002). At this point, where photo-degradation is insensitive to changing CDOM concentrations, the system is "light-limited" - in a light-limited system, as the amount of incident UV light increases so does the rate of photodegradation. In contrast, in very clear waters light attenuation by CDOM is low and rates of DOM photo-degradation are limited by insufficient CDOM to absorb the available light in these 'substrate-limited' systems, increasing the incident UV light has no effect but higher CDOM concentrations increase rates of photo-degradation. Thus, depending on the incident light available, the CDOM concentrations, and the depth of the water column, the rates of DOM degradation in surface waters may be either light-limited, substrate-limited, or co-limited by light and substrate. To our knowledge, the range of conditions and the interactions of controls on photodegradation across the continuum of light- versus substratelimitation have not been described or characterized.

At the scale of a stream reach, lake, or catchment, DOM degradation is related to both photochemical processing and the influence of hydrology on light exposure. Water residence times in a stream or river are generally a function of watershed and channel characteristics, but may also be influenced by surface and subsurface transient storage (e.g., Chapra and Runkel, 1999; Neilson et al., 2010; Zarnetske et al., 2011) and thermal stratification that can isolate water masses (e.g., Merck and Neilson, 2012). While the influence of these factors on biogeochemical processes and solute concentrations has been studied (e.g., Boano et al., 2014; Miller et al., 2009), the relative importance of CDOM concentration and lability, UV exposure, and water residence times on the degradation of DOM is unknown for stream or lake ecosystems.

Running waters, and especially lower-order streams, may be expected to have relatively low DOM degradation in the water column due to their high flow rates and short water residence times. Although small streams are often shallow and if unshaded by riparian vegetation may have light penetration to the bottom, the water residence time in any given reach is short and therefore there is little time for substantial photo-degradation of DOM. However, in areas of low relief, the headwater streams have longer residence times and greater light exposure through a shallow water column. In the Arctic, residence times within low gradient, first-order beaded streams are controlled by thermal stratification of the beads (pools) (Merck et al., 2012; Merck and Neilson, 2012). Strong thermal stratification (up to $10^{\circ} \mathrm{C}$ temperature difference within $0.5 \mathrm{~m}$ depth) observed in Imnavait Creek on the North Slope of Alaska was attributed to a combination of high concentrations of CDOM, low wind stress at the stream surface, underlying frozen soils, and low in-stream discharge (Merck et al., 2012). Because sunlight is rapidly attenuated in high-CDOM waters, warming by solar radiation is restricted to surface layers and can cause strong thermal stratification and density gradients (Fee et al., 1996; Houser, 2006; Kling, 1988). Merck et al. (2012) found that this stratification isolated the pool surface water from the bottom water and increased the water residence times in a reach from minutes under mixed conditions to hours or weeks when the pools were stratified. At the same time, there were distinct gradients in the concentrations of chromophoric and fluorescent fractions of dissolved organic matter (CDOM and FDOM, respectively) between pool surface and bottom waters (Merck et al., 2012). The authors suggested that these gradients in CDOM and FDOM were due to photo-degradation of DOM in the surface waters, and that stratification regulated the residence times of water and DOM and thus controlled the extent of DOM degradation in this stream.

To quantify the role of photo-degradation in producing observed DOM gradients in stratified stream pools, and to generally determine the influence of in-stream stratification, water residence times, and UV exposure on DOM degradation, we measured the lability and rates of DOM degradation by sunlight and bacteria along with changes in CDOM and FDOM within the pools of Imnavait Creek in two summers with differing discharge and stratification patterns. We demonstrate that photo-degradation is the dominant process 
altering DOM chemistry and producing $\mathrm{CO}_{2}$ in the water column of this headwater stream under all conditions, and we show how rates of photo-degradation are governed by the amount and lability of DOM (CDOM), light attenuation, patterns of stratification, and residence time. We suggest that in relatively shallow, high CDOM headwater streams, DOM photo-degradation is limited by available light instead of by available substrate (DOM) under a wide range of hydrological conditions.

\section{Methods}

\subsection{Site description}

Imnavait Creek is a headwater, beaded stream located on the North Slope of Alaska in a glacial valley formed during the Sagavanirktok glaciation in the Kuparuk River basin $\left(68.616^{\circ} \mathrm{N}, 149.318^{\circ} \mathrm{W}\right.$; Detterman et al., 1958; Hamilton, 1986). The creek primarily lies in the organic soil layer and only occasionally cuts through to the mineral soil (McNamara et al., 1998). The connected pools, or beads, were formed by the erosion and melting of large ice deposits that had underlain the creek (McNamara et al., 1998; Walker et al., 1989).

Previous studies of Imnavait Creek found that spring snowmelt accounts for 23 to $75 \%$ of the watershed's annual water flux (Kane et al., 2004; McNamara et al., 2008) compared to 6 to $9 \%$ produced by the largest, single summer storm events (McNamara et al., 2008). Subsurface water paths are limited to the thawed active layer as the region is underlain with up to several hundred meters of permafrost, which effectively separates the active layer from any deep ground water (Osterkamp and Payne, 1981). Typical seasonally thawed active layer depths at Imnavait ranged from 25 to $40 \mathrm{~cm}$, occasionally extending to $100 \mathrm{~cm}$ (Hinzman et al., 1991). Water inputs from the riparian zone occur through both surface and diffuse subsurface flow (Kane et al., 2000). In addition to surface chutes that connect the stream pools, water travels between pools through the riparian zone with both subsurface flow through the active layer and surface flow during significant precipitation events (Merck and Neilson, 2012).

We studied $\mathrm{a} \sim 120 \mathrm{~m}$ reach of the creek consisting of a series of seven pools connected by short chutes (Fig. 1). Pools were named starting with pool 1 and proceeding downstream sequentially to pool 7. Across these seven pools, surface areas ranged from 2 to $129 \mathrm{~m}^{2}$, volumes ranged from 0.2 to $102 \mathrm{~m}^{3}$, and pool depths were between $\sim 0.21$ and $2 \mathrm{~m}$. Along the reach of creek studied, we collected soil water from a water track that drains from the adjacent eastern hillslope into the pools. Seventeen sites were sampled along the water track from the hill top to the valley bottom along the water track with distances between sites ranging from 30 to $190 \mathrm{~m}$. Soil water was also collected from an array of 55

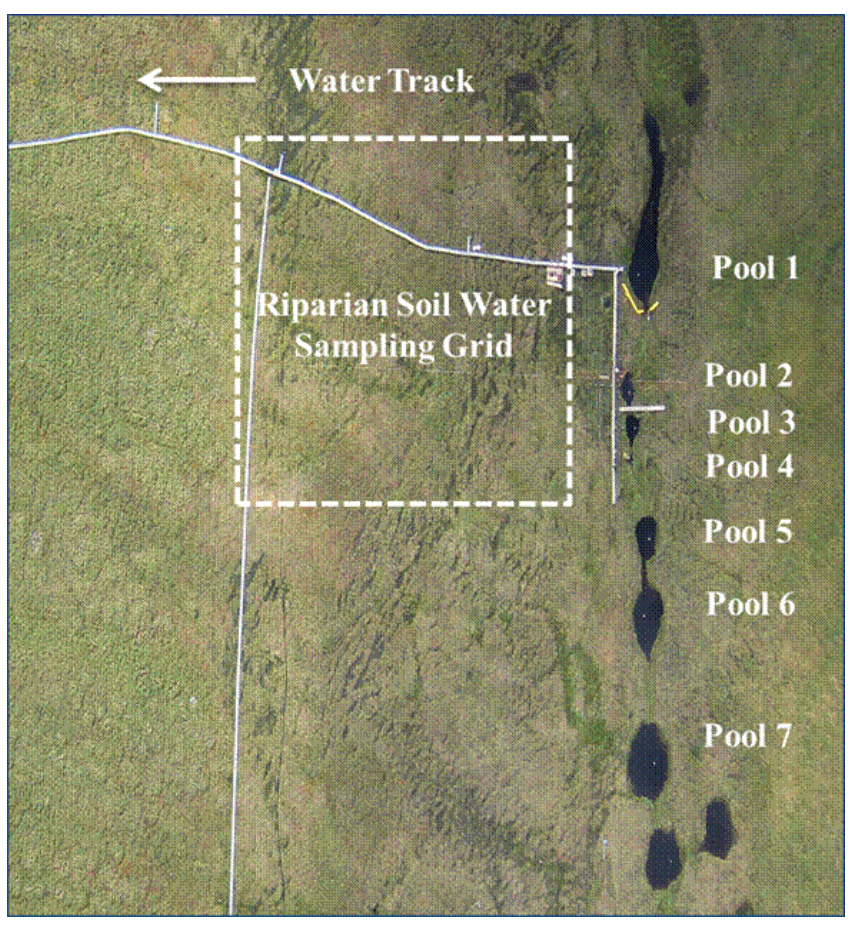

Figure 1. Study area showing the $120 \mathrm{~m}$ reach of Imnavait Creek containing seven consecutive pools, and the locations of soil water collection (riparian zone and water track; only the bottom portion of the water track is shown in this image). Also visible in this areal image as white solid lines are boardwalks installed to access sampling sites.

sites within a 150 by $90 \mathrm{~m}$ grid in a riparian zone on the eastern hillslope adjacent to the study pools in Imnavait Creek (Fig. 1).

\subsection{Water sample collection}

Water samples were collected from the surface and bottom of the seven pools monthly from 23 June through $4 \mathrm{Au}-$ gust 2011, and weekly from 27 June through 18 August 2012. Pool water was collected from the surface and bottom of each pool through MasterFlex ${ }^{\circledR}$ tubing (Cole-Parmer, Vernon Hills, IL) using a peristaltic pump (GeoPump Inc., Medina, $\mathrm{NY)}$. Soil water was collected from the 17 sites in the water track flowing into the pools (Fig. 1), once in June and twice each in July and August in both 2011 and 2012, and from the riparian zone adjacent to the study pools monthly from June through August 2011. From the water track or riparian area, soil water was withdrawn using stainless-steel soil needles inserted into the soil, through MasterFlex ${ }^{\circledR}$ tubing, into plastic syringes. Temperature, conductivity, and $\mathrm{pH}$ were measured from pool and soil water at the time of collection using WTW meters (models 3210; Xylem, White Plains, NY). All pool and soil water samples were filtered in the field into high-density polyethylene bottles and kept cool and dark until analysis. Aliquots for analysis of DOM quantity and 
quality were filtered through pre-combusted Whatman GF/F glass fiber filters (Whatman, Clifton, NJ).

\section{Sunlight attenuation}

Light attenuation with depth was measured in pools 1,2 , 3, and 6 on 27 June 2011 and in pools 1, 2, 3, 6 and 7 on 23 June 2012 using a compact optical profiling system for UV light in natural waters (UV C-OPS; Biospherical Instruments Inc., San Diego, CA) as previously described (Cory et al., 2013, 2014). The C-OPS measured downwelling cosinecorrected irradiance at seven wavebands $(305,313,320,340$, 380,395 , and $412 \mathrm{~nm}$ ) and photosynthetically active radiation (PAR, $400-700 \mathrm{~nm})$. Attenuation coefficients $\left(K_{\mathrm{d}, \lambda}\right)$ were calculated from the downwelling irradiance $\left(E_{\lambda}\right)$ as a function of depth $(z)$ at each waveband:

$E_{\lambda, z}=E_{\lambda, 0} e^{-K_{\mathrm{d}, \lambda z}}$

From multiple casts in each pool ( $n=2$ to 5), the coefficient of variation of $K_{\mathrm{d}, \lambda}$ ranged from 1 to $3 \%$ in the UV and $9 \%$ for PAR. Means \pm standard error (SE) of $K_{\mathrm{d}}$ are reported.

\subsection{In situ monitoring}

Temperature sensor arrays $\left(\mathrm{HOBO}^{\circledR}\right.$ Water Temp Pro v2; Onset Computer Corporation, Inc., Bourne, MA) were deployed vertically in each pool ( $n=1$ to 5 per pool in 2011 and $n=3-25$ per pool in 2012) from late-June through mid-August, measuring at $5 \mathrm{~min}$ intervals. The probes were wrapped with aluminum foil to prevent radiation-caused heating (Neilson et al., 2010) and placed starting 5 to $15 \mathrm{~cm}$ from the bottom of the pool and then at intervals ranging from 5 to $50 \mathrm{~cm}$. Additional monitoring of pool 2 was conducted for 1 week in July 2011 and for most of July and part of August in 2012 where two sondes were deployed near the surface and bottom of the pool with oxygen, $\mathrm{pH}$, specific conductance, and temperature probes (YSI 6920 V2 sonde with ROX $^{\mathrm{TM}}$ optical dissolved oxygen, $6561 \mathrm{pH}, 6560$ conductivity, and 6560 temperature sensors; YSI Inc., Yellow Springs, $\mathrm{OH})$ measuring at $15 \mathrm{~min}$ intervals. Finally, discharge data were collected at a weir further downstream to compare and contrast the flow variability between summer 2011 and 2012 (Kane and Hinzman, 2011; Kane, 2014).

\subsection{Meteorological measurements}

Air temperature $1 \mathrm{~m}$ above the ground and precipitation were measured hourly at a meteorological station on the westfacing ridge of the Imnavait Creek basin approximately $1 \mathrm{~km}$ upstream of the study site using a temperature probe (model HMP45C; Campbell ${ }^{\circledR}$ Scientific, Logan, UT) and tipping bucket rain gauge, respectively (Kane and Hinzman, 2011). Global solar, UVA and UVB radiation were each measured at $5 \mathrm{~min}$ intervals at Toolik Field Station (TFS, $11 \mathrm{~km}$ West of Imnavait at $68.616^{\circ} \mathrm{N}, 149.318^{\circ} \mathrm{W}$ ) with pyranometers from
Kipp \& Zonen (CMP-6) and Yankee Environmental System, Inc. (UVB-1 and UVA-1), respectively. The global solar pyranometer measured a spectral range of 310 to $2800 \mathrm{~nm}$, while UVB and UVA pyranometers measured 280-320 and $320-400 \mathrm{~nm}$, respectively. Photosynthetically active radiation (PAR; 400-700 nm) was measured hourly using a quantum sensor by Li-Cor (LI-190S) at the same location.

\subsection{DOM quantity and quality}

Samples for dissolved organic carbon (DOC) concentration were acidified with trace-metal grade hydrochloric acid to approximately $\mathrm{pH} 3$ after filtration through Whatman GF/F filters and stored in the dark at $4{ }^{\circ} \mathrm{C}$ until analysis using a high-temperature platinum-catalyzed combustion followed by infrared detection of $\mathrm{CO}_{2}$ (Shimadzu TOC-V; Shimadzu, Columbia, MD).

The chromophoric and fluorescent fractions of DOM (CDOM and FDOM, respectively) were analyzed within hours to at most several days of collection. Samples were stored in the dark at $4{ }^{\circ} \mathrm{C}$ until warmed to room temperature (20 to $25^{\circ} \mathrm{C}$ ) just prior to analysis. UV-Vis absorbance spectra of CDOM were collected using $1 \mathrm{~cm}$ path length quartz cuvettes with a spectrophotometer (USB 2000+ UV-VIS; Ocean Optics, Inc., Dunedin, FL or Aqualog; Horiba Scientific). Sample absorption was measured against laboratorygrade deionized (DI) water blanks (Barnstead E-Pure and B-Pure; Barnstead Thermolyne, Dubuque, IA). The spectral slope ratio $\left(S_{\mathrm{R}}\right)$ was calculated from the absorbance spectrum of each sample as the ratio of the slope from 275 to $295 \mathrm{~nm}$ to the slope from 350 to $400 \mathrm{~nm}$ (Helms et al., 2008). CDOM absorption coefficients $\left(a_{\mathrm{CDOM}, \lambda}\right)$ were calculated as follows:

$a_{\mathrm{CDOM}, \lambda}=\frac{A_{\lambda}}{l} 2.303$,

where $A$ is the absorbance reading at wavelength $\lambda$ and $l$ is the pathlength in meters. SUVA 254 was calculated as absorbance at $254 \mathrm{~nm}$ divided by the cuvette pathlength $(\mathrm{m})$ and then divided by the DOC concentration $\left(\mathrm{mg} \mathrm{CL}^{-1}\right.$; Weishaar et al., 2003).

Excitation-emission matrices (EEMs) were measured on all water samples with a Fluoromax-4 fluorometer or an Aqualog (Horiba Scientific, Edison, NJ) following previously described procedures (Cory et al., 2010). An aliquot of sample was placed in the $1 \mathrm{~cm}$ quartz cuvette for each EEM and diluted with DI if necessary to bring $A_{254}<0.6$. EEMs were corrected for inner-filter effects and for instrumentspecific excitation and emission corrections in Matlab (version 7.7) following Cory et al. (2010). The fluorescence index (McKnight et al., 2001) was calculated from each corrected EEM as the ratio of emission intensity at $470 \mathrm{~nm}$ over the emission intensity at $520 \mathrm{~nm}$ at an excitation wavelength of $370 \mathrm{~nm}$ (Cory et al., 2010). Emission intensity at FDOM peaks $\mathrm{A}, \mathrm{C}$, and $\mathrm{T}$ was evaluated at excitation/emission pairs 
250/450, 350/450, 275/340 (nm/nm), respectively, in Raman Units (RU; Stedmon et al., 2003).

\subsection{DOM degradation}

Water collected from Imnavait Creek in amber HDPE bottles in the field was used for photochemical and bacterial degradation experiments, as described in Cory et al. (2014). Briefly, dark bacterial respiration was measured from whole water samples incubated for 5 to 7 days in the dark at 6$7^{\circ} \mathrm{C}$ alongside killed controls $\left(1 \% \mathrm{HgCl}_{2}\right)$ in air-tight, precombusted $12 \mathrm{~mL}$ borosilicate exetainer vials (Labco, Inc). For DOM photo-degradation, GF/F filtered water was placed in air-tight, pre-combusted $12 \mathrm{~mL}$ borosilicate exetainer vials and exposed to natural sunlight at Toolik Field Station for $\sim 12$ hours alongside foil-wrapped dark controls at temperatures ranging from 10 to $16^{\circ} \mathrm{C}$. Bacterial re-growth experiments for photo-stimulated bacterial respiration were conducted as described in Cory et al. $(2013,2014)$. There were four independent replicates from each water sample for every analysis type and treatment. Membrane inlet mass spectrometry (MIMS) was used to measure bacterial or photochemical oxygen consumption relative to killed or dark controls, respectively. Bacterial or photochemical production of $\mathrm{CO}_{2}$ during complete oxidation (mineralization) of DOM was quantified as production of dissolved inorganic carbon (DIC) relative to killed or dark controls, respectively, using a DIC analyzer (model AS-C3, Apollo SciTech, Inc.). After exposure to sunlight or bacteria, subsamples were analyzed for CDOM and FDOM as described above. Changes in DOM quality are reported as mean \pm standard error (SE) of the four replications of each treatment.

We used previously reported lability and rates of DOM degradation by bacteria and sunlight in Imnavait Creek, measured from experiments described above, during our study periods in 2011 and 2012 to determine the sensitivity of DOM degradation in Imnavait Creek to photochemical and hydrological factors. The conversion of experimental measures of DOM degradation to water column rates of degradation is described for Imnavait Creek and other waters in the Arctic in Cory et al. (2013, 2014). In the current study, we quantified how rates of DOM photo-degradation in the water column varied with available light, CDOM concentrations, and lability of DOM measured in Imnavait Creek during the 2011-2012 summer seasons.
The integrated, water-column rate of DOM photodegradation is as follows:

Photo-degradation $\left(\operatorname{mol~C~m}{ }^{-2} \mathrm{~d}^{-1}\right)=$
$\int_{\lambda_{\min }}^{\lambda_{\max }} \phi_{\lambda} Q_{\mathrm{dso}, \lambda}\left(1-e^{-K_{\mathrm{d} \lambda} z}\right) \frac{a_{\mathrm{CDOM} \lambda}}{a_{\mathrm{tot} \lambda}} \mathrm{d} \lambda$,

where $\lambda_{\min }$ and $\lambda_{\max }$ are the minimum and maximum wavelengths of light contributing to the photo-degradation of DOC (280 and $700 \mathrm{~nm}$, respectively). $\Phi_{\lambda}$ is the apparent quantum yield spectrum for photo-degradation of DOM (mol product $\mathrm{mol}^{-1}$ photons absorbed $\mathrm{nm}^{-1}$; a measure of DOM lability to photo-degradation which decreases exponentially with increasing wavelength). We used previously reported spectra of DOM lability $\left(\Phi_{\lambda}\right)$ in Imnavait Creek for photomineralization DOC to $\mathrm{CO}_{2}$ and photo-stimulated bacterial respiration (Cory et al., 2014). $Q_{\mathrm{dso}, \lambda}$ is the spectrum of the UV from sunlight that reaches the water surface (accounting for reflection; Cory et al. 2014). $Q_{\mathrm{dso}, \lambda}$ varies by location (latitude/longitude), time of day, date, and sunny vs. cloudy sky conditions, as described in Cory et al. 2014. $K_{\mathrm{d}, \lambda}$ is the attenuation coefficient with depth (Eq. 1). $a_{\mathrm{CDOM}, \lambda}$ is the concentration of CDOM measured as described above (Eq. 2). $a_{\mathrm{CDOM}, \lambda} / a_{\mathrm{tot}, \lambda}$ is the spectrum of the ratio of absorption by CDOM to the total absorption (where $a_{\text {tot }, \lambda}$ is the total absorption in the water column due to CDOM, particles, and water). The ratio of $a_{\mathrm{CDOM}, \lambda} / a_{\mathrm{tot}, \lambda}$ was assumed to be 1 at all wavelengths (i.e., CDOM was the main UV-absorbing constituent in Imnavait Creek; Cory et al., 2014).

From Eq. 3, it follows that as DOM lability to photodegradation $\left(\Phi_{\lambda}\right)$ or incoming UV light $\left(Q_{\mathrm{dso}, \lambda}\right)$ increases, the depth-integrated or areal water-column rate of DOM photo-degradation increases. In addition, photo-degradation of DOM throughout the water column increases with increasing $K_{\mathrm{d}, \lambda}$ up to a point where at high $K_{\mathrm{d}, \lambda}$ the relationship is asymptotic (Fig. S1). This is because while increasing CDOM provides more DOM to absorb light and photo-degrade, the absorption of UV light by CDOM also controls light attenuation (i.e., $a_{\mathrm{CDOM}, \lambda} \approx K_{\mathrm{d}, \lambda}$; presented in the Results section below). Thus as light attenuation $\left(K_{\mathrm{d}, \lambda}\right)$ increases, at some point light becomes limiting and adding more CDOM (increasing $K_{\mathrm{d}}$ ) results in no change in the integrated water column rate of photo-degradation (Fig. S1). In this study, we used the range of terms in Eq. (3) observed in Imnavait Creek (Fig. S2) to develop a conceptual model of controls on DOM photo-degradation in this and similar systems. For example, we used the range of $Q_{\mathrm{dso}, \lambda}$ spectra for Imnavait Creek representing the average, minimum and maximum UV light reaching the surface of Imnavait Creek over the course of the day during the study period, as well as the average, minimum and maximum of $a_{\mathrm{CDOM} \lambda}$ observed in Imnavait Creek. 

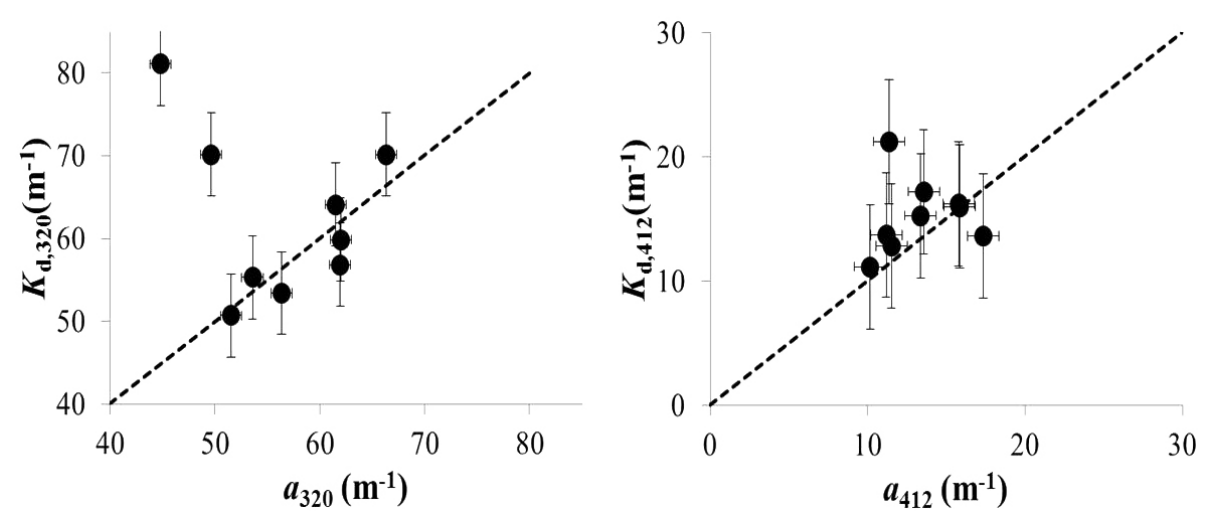

Figure 2. $K_{\mathrm{d}, \lambda}$ vs. $a_{\mathrm{CDOM}, \lambda}$ at $320 \mathrm{~nm}$ (left) and $412 \mathrm{~nm}$ (right) plotted vs. $1: 1$ line (dotted line). $a_{\mathrm{CDOM}, \lambda}$ measured on the laboratory spectrophotometer was corrected for the average cosine of downwelling radiation for the time of day (i.e., zenith angle) that the in situ $K_{\mathrm{d}, \lambda}$ values were measured in Imnavait Creek. Thus $a_{\mathrm{CDOM}, \lambda}$ values in this figure are not directly comparable to the values presented in Tables 2 and 3 .

\section{Results}

\subsection{Meteorological conditions}

There was no difference in mean air temperatures between the mid-June through mid-August study periods in $2011 \mathrm{vs.}$ 2012 at Imnavait Creek. However, June-August was generally sunnier and drier in 2011 compared to 2012 (Table 1). The total global solar radiation (310-2800 nm) and total UV and visible photon flux $(280-700 \mathrm{~nm})$ were 17 and $24 \%$ higher, respectively, in 2011 compared to 2012 (Table 1, Fig. S3). Precipitation was three times greater during the summer of 2012 compared with 2011, and the lower precipitation in 2011 resulted in a significantly lower volume of water passing the weir in 2011 versus 2012 (Table 1, Fig. S1).

\subsection{Pool stratification and separation of water masses}

Light attenuation coefficients $\left(K_{\mathrm{d}, \lambda}\right)$ in Imnavait Creek decreased exponentially with increasing wavelength from $88 \pm 12 \mathrm{~m}^{-1}$ at $305 \mathrm{~nm}$ to $17 \pm 3 \mathrm{~m}^{-1}$ at $412 \mathrm{~nm}$ to $3 \pm 1 \mathrm{~m}^{-1}$ in the photosynthetically active region (PAR). In most pools, there was no significant difference between in situ $K_{\mathrm{d}, \lambda}$ values and CDOM absorption coefficients $\left(a_{\mathrm{CDOM}, \lambda}\right)$ collected from filtered water from the same pool at the time $K_{\mathrm{d}, \lambda}$ was measured (as shown for 320 and $412 \mathrm{~nm}$ in Fig. 2). These results demonstrate that in most pools $\mathrm{CDOM}$ was the dominant light absorbing constituent in the water column (Fig. 2), consistent with low particulate matter concentrations in this stream and previous work showing that CDOM dominates UV light absorption in these streams (Cory et al. 2014). However, in two pools sampled in June 2011, the in situ $K_{\mathrm{d}, \lambda}$ values at $320 \mathrm{~nm}$ were significantly higher than the corresponding CDOM absorption coefficients measured from filtered water (Fig. 2). This was likely due to the inherent challenges deploying an instrument to quantify $K_{\mathrm{d}, \lambda}$ in the UVB range in high CDOM waters where $99 \%$ of light at $320 \mathrm{~nm}$ is attenuated by $\sim 8 \mathrm{~cm}$ (based on the mean $K_{\mathrm{d}, \lambda}$ or CDOM coefficients in Fig. 2).

Five of the seven pools $(2,3,5,6,7)$ were repeatedly thermally stratified with a nearly $10^{\circ} \mathrm{C}$ temperature difference between top and bottom waters during sunny and dry (lowflow) conditions in Imnavait Creek (Figs. 3 and 4). In contrast, pools 1 and 4 did not exhibit stratification in 2011 or 2012. During the sunnier and drier summer of 2011, pools $2,3,5,6,7$ were stratified on 43 to 46 out of 50 days measured (Fig. 3), while during the wetter summer of 2012, these pools stratified only 11 out of 49 days measured (Fig. 4). Within each summer, the roles of solar radiation and precipitation were evident in the frequency and extent of stratification in each pool. For example, pools 2, 3, 5, 6, and 7 showed the greatest extent of thermal stratification once the discharge from snowmelt had receded, coinciding with the period when solar irradiance was highest (e.g., late June in 2011 and 2012; Figs. 3, 4). In addition, during both summers a portion of each stratified pool mixed nightly due to surface heat loss, followed by re-stratification with increasing solar irradiance during the day (Merck and Neilson, 2012). Following substantial precipitation events, stream flow increased and caused stratified pools to mix completely within hours of precipitation, as demonstrated for example after a rain event on 17 July 2011 (Fig. 3). After mixing, pools stratified again within 4 to 5 days (Fig. 3 ).

Under stratified conditions, water and DOM in the pools experienced contrasting UV exposure. For example, Pool 3 had a depth of $1.4 \mathrm{~m}$ from the water surface to the sediment, and on average the depth of the surface mixing layer was $50 \mathrm{~cm}$ (ranging from $20-50 \mathrm{~cm}$ below the water surface; Fig. 3). It follows that DOM below $50 \mathrm{~cm}$ was in the "bottom water", defined as water trapped below the diel mixing depth during stratified conditions. The depth of UVB and UVA light penetration was always less than $50 \mathrm{~cm}$ in Imnavait Creek. For example, using the mean CDOM absorp- 
Table 1. Meteorological conditions at Toolik Field Station during study periods.

\begin{tabular}{|c|c|c|c|c|c|}
\hline Period & $\begin{array}{l}\text { Global solar } \\
\text { radiation }^{\mathrm{a}} \\
\mathrm{kW} \mathrm{m}^{-2}\end{array}$ & $\begin{array}{l}\text { UV+Visible } \\
\text { Photon Flux }^{\mathrm{a}} \\
\text { mol photons m }{ }^{-2}\end{array}$ & $\begin{array}{l}\text { Air temperature } \\
(1 \mathrm{~m}) \\
{ }^{\circ} \mathrm{C}\end{array}$ & $\begin{array}{l}\text { Precipitation }^{\mathrm{a}} \\
\mathrm{mm}\end{array}$ & $\begin{array}{l}\text { Total discharge } \\
\text { at weir }{ }^{\mathrm{c}} \\
\mathrm{m}^{3}\end{array}$ \\
\hline 2011 & 12 & 2111 & 9 & 63 & $41 \times 10^{3}$ \\
\hline 2012 & 10 & 1600 & 10 & 189 & $233 \times 10^{3}$ \\
\hline
\end{tabular}

${ }^{a}$ Sum of daily average values from 23 June through 18 August in each year (sampling periods in 2011 and 2012). ${ }^{b}$ Daily average value from 23 June through 18 August. ${ }^{c}$ Sum discharge passing the weir at Imnavait from 28 June to 18 August.

Table 2. Annual average hydrologic and chemical characteristics of soil and stream water samples from Imnavait Creek.

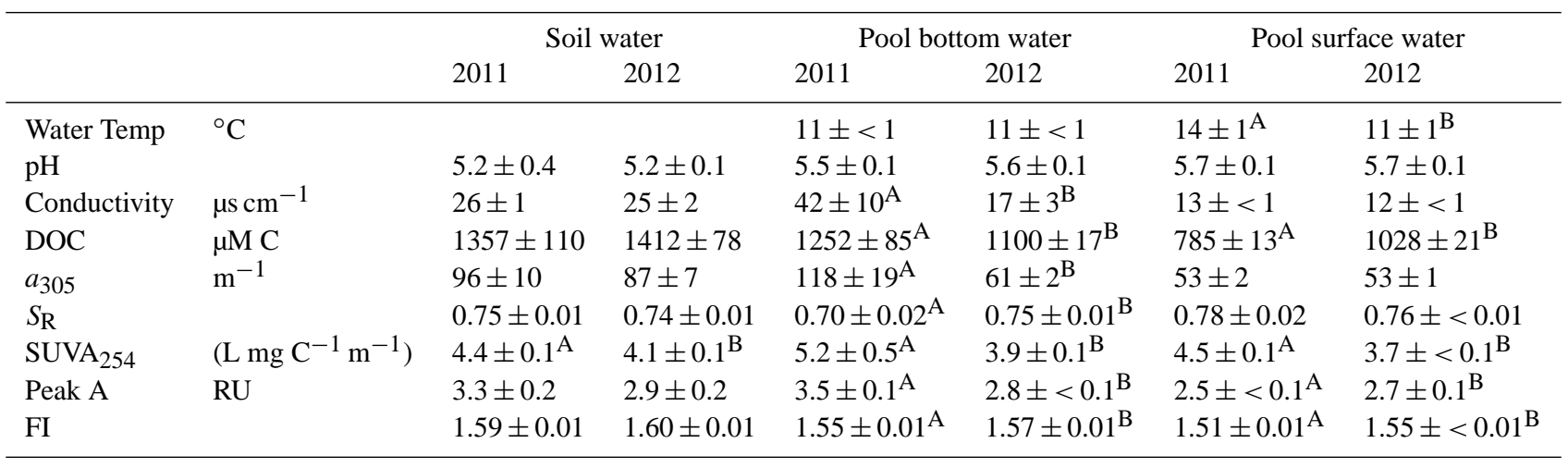

All values are seasonal averages \pm standard error across all dates in 2011 or 2012. Letters A and B indicate significant difference $(p<0.05)$ in mean values between years (2011 vs. 2012) for each water type (soil waters, pool bottom waters, and pool surface waters).

tion coefficients at 320 and $412 \mathrm{~nm}$ (Fig. 2), $99 \%$ of all incoming UVB and UVA light was absorbed within $8 \pm 1 \mathrm{~cm}$ and $35 \pm 3 \mathrm{~cm}$, respectively (average $\pm \mathrm{SE}$; maximum depth of UVA penetration observed was $45 \mathrm{~cm}$ based on attenuation coefficients at $412 \mathrm{~cm}$ in Fig. 2). Therefore, DOM in the surface of the pools experienced UV light exposure each day while DOM trapped in pool bottom waters was protected from UV light during stratified conditions.

\subsection{Stream and soil water chemistry}

Both the pool water and the soil water draining into Imnavait Creek had low $\mathrm{pH}$, low conductivity, and high concentrations of DOC, CDOM, and FDOM (Table 2). The $\mathrm{pH}$ ranged from $5.2 \pm 0.1$ to $5.7 \pm 0.1$ and the conductivity ranged from $25 \pm 10$ to $12 \pm 2 \mu \mathrm{S} \mathrm{cm}^{-1}$ in soil and pool water, respectively. DOC concentrations ranged from $1412 \pm 78$ and $785 \pm 13 \mu \mathrm{M} \mathrm{C}$ in pool and soil water, respectively, during summer of 2012 (Table 2). CDOM and FDOM proxies for the chemical composition of soil and pool water DOM were consistent with a terrestrial source of DOM, i.e., high molecular weight, aromatic compounds derived from degradation of plant and soil organic matter. For example, in the soil waters draining to Imnavait Creek, the spectral $S_{\mathrm{R}}$, a proxy for average molecular weight of DOM (Helms et al., 2008) was $0.75 \pm 0.08$, and the specific UV absorbance at $254 \mathrm{~nm}\left(\mathrm{SUVA}_{254}\right)$, strongly correlated with aromatic $\mathrm{C}$ content, was $4.4 \pm 0.1 \mathrm{~L} \mathrm{mg} \mathrm{C}^{-1} \mathrm{~m}^{-1}$. The fluorescence index, a proxy for DOM source and aromatic $\mathrm{C}$ content, was $1.59 \pm 0.01$. Although there were some significant differences in mean values between soil and pool water DOC, CDOM and FDOM (discussed below), similar ranges of DOC, CDOM and FDOM were observed for the pool bottom waters in Imnavait Creek and for the soil water draining into the pool bottoms (Table 2).

There were no significant differences in average $\mathrm{pH}$, conductivity, DOC, CDOM, or FDOM concentrations in the soil waters between 2011 and 2012 (Table 2). There was no difference in average optical character of soil water DOM between summers except for $\mathrm{SUVA}_{254}$, which was significantly lower in the soil waters in 2012 compared to 2011 (Table 2). In contrast, there were significant differences in DOM quality between 2011 and 2012 when comparing pool bottom or surface water across years (Table 2), likely due to differences in the extent of stratification between years.

When the pools in Imnavait Creek were stratified, there were significant differences in water chemistry between pool surface and bottom water. In situ data collected under stratified conditions in Pool 2 from 8-15 July 2011 showed significantly higher dissolved oxygen in the surface compared to the bottom pool water (Fig. 3). Discrete water samples collected when pools were stratified in 2011 and 2012 showed significantly higher concentrations of DOC, CDOM, and FDOM in bottom waters compared to surface waters (as 


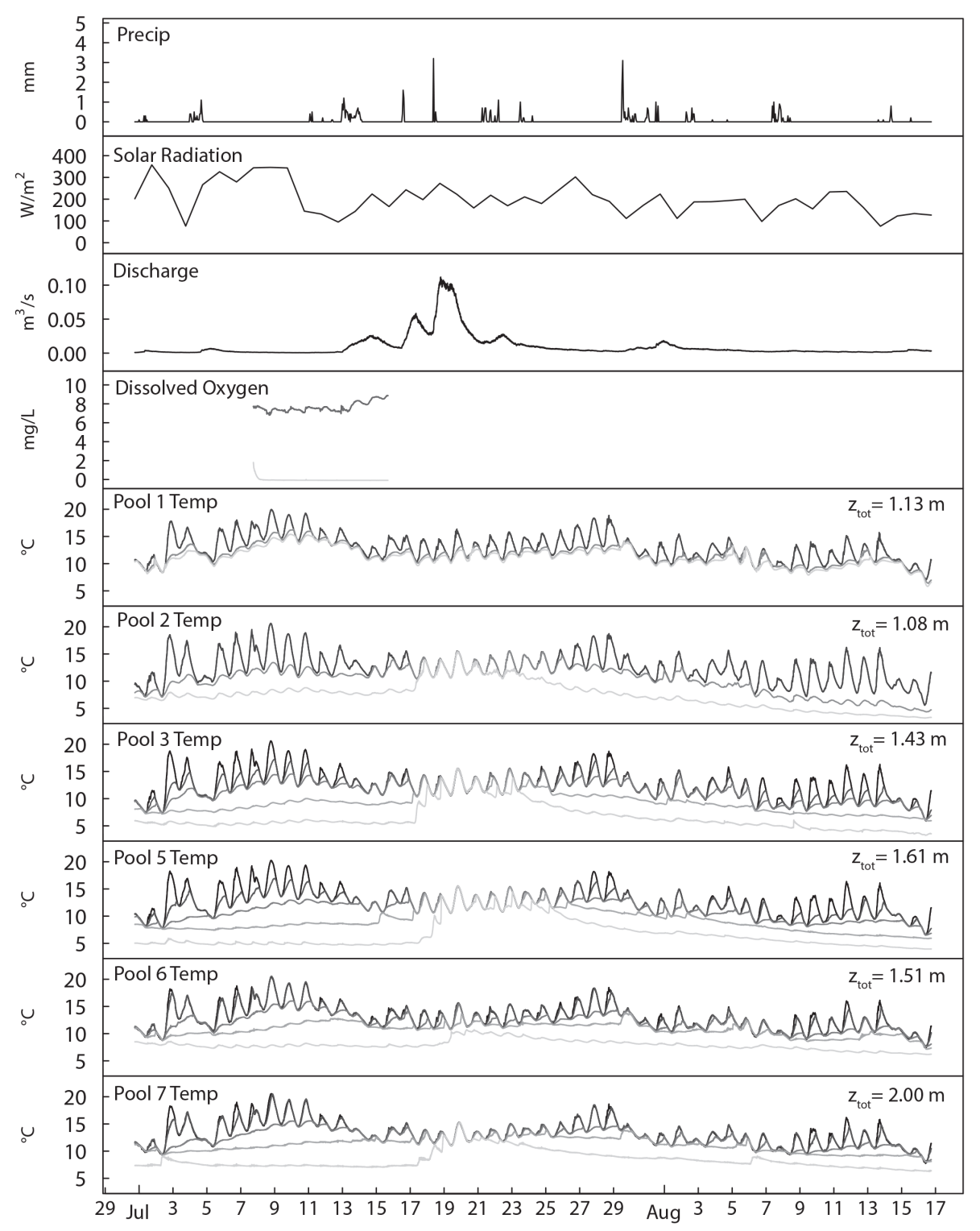

Figure 3. Imnavait Creek precipitation, solar radiation, discharge (at location downstream of study reach), dissolved oxygen in pool 2 top and bottom, and vertical arrays (VA) of temperature sensors within each study pool $(P)$ in summer 2011. The darkest lines represent the sensor at the top of the water column; subsequent lines become lighter with depth of each sensor. The sensors were placed in each pool starting 5 to $15 \mathrm{~cm}$ from the bottom of the pool and then at intervals ranging from 5 to $50 \mathrm{~cm}$ over the depth of each pool $\left(z_{\text {tot }}\right)$ as indicated in the figure.

shown in Fig. 5 for pools sampled on 14 July 2011). The surface waters of most pools sampled under stratified conditions had different DOM quality compared to bottom waters, as indicated by significantly lower $\mathrm{SUVA}_{254}$, higher $S_{\mathrm{R}}$, and lower FI (Table 3; Fig. 5). When the stream pools stratified, DOM in pool bottom water was not significantly different than soil water for most CDOM and FDOM measures or DOM quantity and quality (Table 3). In contrast, when the pools were mixed, there were no significant differences in DOC, CDOM, and FDOM between pool surface and bottom waters (e.g., as shown in Fig. 5 for pools sampled on 21 July 2012).

\subsection{Photochemical degradation of DOM}

Previous work showed that photo-mineralization of DOM to $\mathrm{CO}_{2}$ accounted for the majority of DOM degradation in Imnavait Creek $\left(24.69 \pm 18.28 \mathrm{mmol} \mathrm{C} \mathrm{m}^{-2} \mathrm{~d}^{-1}\right.$, mean $\pm \mathrm{SE}$; Cory et al., 2014). Here we show that in addition to mineralization of DOM, exposure of Imnavait Creek DOM to $\sim 12 \mathrm{~h}$ of sunlight altered the chemical quality of the remaining DOM, likely due to preferential mineralization of the aromatic fraction (Cory et al., 2007; Stubbins et al., 2010) and to partial photo-oxidation of the DOM (Cory et al., 2013, 2014). These photochemical alterations of DOM resulted in 
Table 3. DOM in soil waters compared to pool water in Imnavait Creek under stratified conditions.

\begin{tabular}{lllll}
\hline & & $\begin{array}{l}\text { Soil } \\
\text { water }\end{array}$ & $\begin{array}{l}\text { Pool bottom } \\
\text { water }\end{array}$ & $\begin{array}{l}\text { Pool surface } \\
\text { water }\end{array}$ \\
\hline DOC & $\mu \mathrm{M} \mathrm{C}$ & $1382 \pm 69$ & $1188 \pm 56$ & $815 \pm 12$ \\
$a_{305}$ & $\mathrm{~m}^{-1}$ & $92 \pm 6$ & $100 \pm 13$ & $50 \pm 1$ \\
$S_{\mathrm{R}}$ & & $0.75 \pm 0.01$ & $0.71 \pm 0.01$ & $0.77 \pm 0.01$ \\
SUVA $_{254}$ & $\left(\mathrm{~L} \mathrm{mg} \mathrm{C}^{-1} \mathrm{~m}^{-1}\right)$ & $4.4 \pm 0.1$ & $4.9 \pm 0.3$ & $4.2 \pm 0.1$ \\
Peak A & $\mathrm{RU}$ & $3.1 \pm 0.2$ & $3.2 \pm 0.1$ & $2.38 \pm 0.05$ \\
FI & & $1.60 \pm 0.01$ & $1.57 \pm 0.01$ & $1.52 \pm 0.01$ \\
\hline
\end{tabular}

All values shown as average \pm standard error; calculated in the pool surface or bottom across all dates in 2011 and 2012 when pools were stratified (2011: 27 June, 29 June, 14 July, 4 August; 2012:

23 June, 30 June). Soil water means were calculated over both years (2011-2012). All water types

were statistically different from one another for all variables (ANOVA $p<0.01$ ).

Table 4. Effect of sunlight and bacteria on CDOM, FDOM and DOM mineralization.

\begin{tabular}{|c|c|c|c|c|c|c|c|c|}
\hline Process & $\begin{array}{l}a_{305} \\
m^{-1}\end{array}$ & $S_{\mathrm{R}}$ & $\begin{array}{l}\mathrm{SUVA}_{254} \\
\mathrm{~L} \mathrm{mg} \mathrm{C}-1 \mathrm{~m}^{-1}\end{array}$ & FI & $\begin{array}{l}\text { Peak A } \\
\text { RU }\end{array}$ & $\begin{array}{l}\text { Peak C } \\
\text { RU }\end{array}$ & $\begin{array}{l}\text { Peak T } \\
\text { RU }\end{array}$ & $\begin{array}{l}\text { Mineralization } \\
\text { rate } \\
\left(\mathrm{mmol} \mathrm{C} \mathrm{m}^{-2} \mathrm{~d}^{-1}\right)\end{array}$ \\
\hline $\begin{array}{l}\text { Photo- } \\
\text { degradation }^{\mathrm{a}}\end{array}$ & $-12.4 \pm 1.8$ & $15.8 \pm 1.3$ & $-4.9 \pm 0.01$ & $-11.7 \pm 0.8$ & $-12.1 \pm 1.4$ & $-27.2 \pm 2.1$ & $4.1 \pm 1.5$ & $24.7 \pm 18.3$ \\
\hline $\begin{array}{l}\text { Bacterial } \\
\text { degradation }^{\mathrm{b}}\end{array}$ & $-2.9 \pm 1.6$ & ND & $5.0 \pm 0.03$ & ND & $-7.6 \pm 2.4$ & $-3.6 \pm 1.5$ & $-2.5 \pm 8.2$ & $2.35 \pm 0.34$ \\
\hline $\begin{array}{l}\text { Photo }+ \\
\text { bacterial degradation }\end{array}$ & $3 \pm 1$ & $1 \pm 1$ & NM & $5 \pm 1$ & $7 \pm 1$ & $15 \pm 1$ & $-12 \pm 1$ & $3.04 \pm 1.31$ \\
\hline
\end{tabular}

a significant loss of CDOM and FDOM at each wavelength compared to dark controls $(12.1 \pm 1.4 \%$ to $27.2 \pm 2.1 \%$ less CDOM or FDOM compared to the dark control depending on CDOM wavelength or FDOM peak, Table 4). Because there was a greater loss of CDOM at long wavelengths compared to shorter wavelengths, photo-degradation significantly increased the $S_{\mathrm{R}}$ by $15.8 \pm 1.3 \%$ and decreased the FI by $-11.7 \pm 0.8 \%$ on average. There was an increase in peak $\mathrm{T}$ intensity by $4.1 \pm 1.5 \%$ for photo-exposed DOM compared to dark controls (Table 4 ).

Photo-degradation of DOM increased bacterial respiration compared to bacterial respiration of DOM kept in the dark. The water column rate of photo-stimulated bacterial respiration was $3.04 \pm 1.31 \mathrm{mmol} \mathrm{C} \mathrm{m}^{-2} \mathrm{~d}^{-1}$ (Cory et al., 2014). Relative to the initial photo-exposed DOM, bacterial incubation generally increased CDOM and FDOM (from $3 \pm 1$ to $15 \pm 1 \%$, Table 4). The exception was that following bacterial degradation of the photo-exposed DOM, there was a $12 \pm 1 \%$ loss of peak $T$ fluorescence (Table 4). Coupled photo and bacterial degradation increased the fluorescence index by $5 \pm 1 \%$ (Table 4 ).

\subsection{Bacterial degradation of DOM}

The average areal rate of dark bacterial respiration of DOM integrated over the mean depth $(0.5 \mathrm{~m})$ in Imnavait Creek was $2.35 \pm 0.34 \mathrm{mmol} \mathrm{O}_{2} \mathrm{~m}^{-2} \mathrm{~d}^{-1}$. Bacterial degradation resulted in a significant loss of CDOM and FDOM compared to the killed control over the 6-day incubation period at 6 $7{ }^{\circ} \mathrm{C}(-2.9 \pm 1.6$ to $-7.6 \pm 2.4 \%$, Table 4$)$. There was no detectable change in the $S_{\mathrm{R}}$ or the FI after dark bacterial degradation of DOM compared to the killed control (Table 4).

\section{Discussion}

\subsection{Stratification in beaded streams}

Stratification is likely widespread during the summer in beaded pools and small ponds across the Arctic. Stratification in tundra ponds is well documented (Hobbie, 1980), as are the factors conducive to stratification including high light attenuation by CDOM (Cory et al., 2007, 2014; Gareis et al., 2010; Watanabe et al., 2011), adequate solar radiation, and in streams with low wind stress at the surface and low enough discharge coupled with permafrost below the stream (Merck and Neilson, 2012; Merck et al., 2012; this study). For example, nearly one third of both lower-order streams 


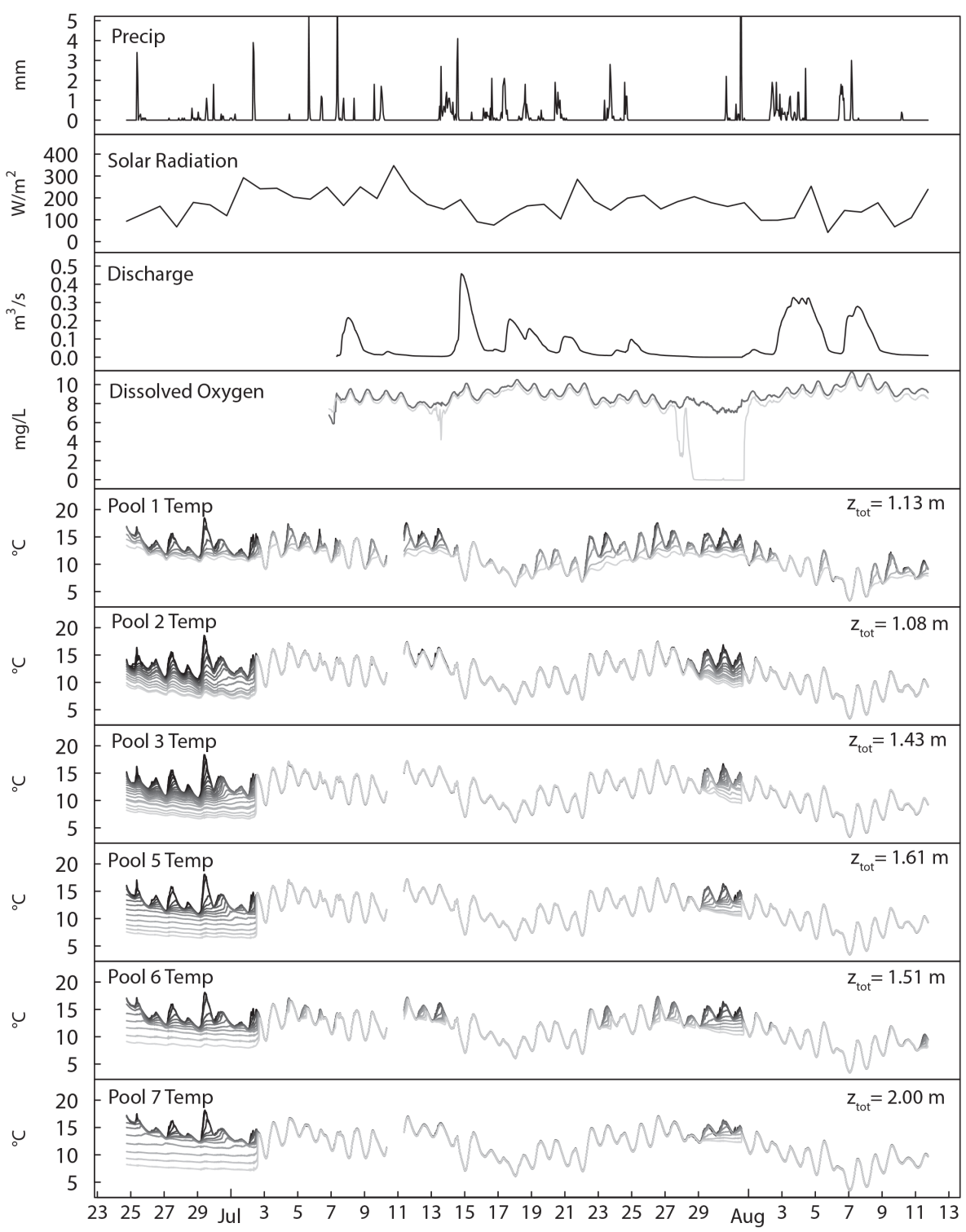

Figure 4. Imnavait Creek precipitation, solar radiation, discharge (at location downstream of study reach), dissolved oxygen in pool 2 top and bottom, and vertical arrays (VA) of temperature sensors within each study pool $(P)$ in summer 2012. The darkest lines represent the sensor at the top of the water column; subsequent lines become lighter with depth of each sensor. The sensors were placed in each pool starting 5 to $15 \mathrm{~cm}$ from the bottom of the pool and then at intervals ranging from 5 to $50 \mathrm{~cm}$ over the depth of each pool $\left(z_{\text {tot }}\right)$ as indicated in the figure.

and coastal plain lakes sampled in the Alaskan Arctic had average CDOM absorption coefficients at $305 \mathrm{~nm}$ greater than or equal to the absorption coefficients observed in the surface of Imnavait Creek (Cory et al., 2014), consistent with high CDOM absorption coefficients reported in streams and small ponds and lakes across the Arctic (Gareis et al., 2010; Watanabe et al., 2011). While fewer studies have reported in situ $K_{\mathrm{d}, \lambda}$ values compared to reports of CDOM absorption coefficients in arctic freshwaters, strong agreement between $K_{\mathrm{d}, \lambda}$ and $a_{\mathrm{CDOM}, \lambda}$ in this and other studies (Fig. 2; Cory et al., 2014; Gareis et al., 2010; Morris et al., 1995) demonstrate that CDOM was the main UV and visible (PAR) light absorb- ing constituent in surface waters across the Arctic. Because UV and PAR account for approximately $51 \%$ of the energy within the shortwave radiation portion of the spectrum (300$2500 \mathrm{~nm}$ ), absorption of sunlight by CDOM contributes to the frequency and extent of stratification by restricting warming to the surface layers (Caplanne and Laurion, 2008; Merck and Neilson, 2012).

Given that there was no significant difference in the average CDOM absorption coefficients in pool surface waters between 2011 and 2012 (Table 3), or between pool bottom water temperatures or in wind stress (Table 1), differences in the extent and frequency of stratification in the pools between 
years were most likely due to differences in discharge (Table 1; Fig. S1). Low in-stream discharges common in 2011 were due to significantly less precipitation than in 2012. Low discharge led to low turbulence, allowing for more common thermal stratification in the pools throughout a large fraction of the open water season (Table 1, Fig. 3). The higher flows during summer 2012 resulted in approximately fivefold greater stream volume compared to 2011, which increased the turbulence that induced frequent mixing throughout the water column in the pools (Table 1; Fig. 4).

\subsection{DOM composition and photo-degradation}

There are three lines of evidence in support of photodegradation as the main control on the observed differences in DOM quantity and composition between pool surface and bottom waters in Imnavait Creek under stratified conditions: (1) water column rates of photo-mineralization of DOM and photo-stimulated bacteria respiration each exceeded dark bacterial respiration (Cory et al., 2014; Table 4), (2) experimental photo-degradation of Imnavait DOM closely reproduced the depth differences in DOM concentration and composition (Table 4), and (3) depth differences in DOM concentration and composition were consistent with effects of sunlight on DOM observed in other studies.

The mean water column rate of photo-mineralization of DOM to $\mathrm{CO}_{2}$ was about 10 times faster than photostimulated bacterial respiration or dark bacterial respiration in Imnavait Creek (Cory et al., 2014, Table 4). Thus, although $99 \%$ of all UVB and UVA light causing photomineralization of DOM was attenuated within 8 to $35 \mathrm{~cm}$ below the pool surface, respectively (Fig. 2), thereby confining photo-degradation of DOM to the top $\sim 35 \mathrm{~cm}$ of the pool, photo-mineralization in this surface layer was fast enough to exceed rates of bacterial respiration occurring throughout the UV-exposed and UV-protected portions of the water column (Table 4).

The second line of evidence in support of photodegradation as the dominant process creating differences in DOM character between surface and bottom waters was that photo-degradation experiments reproduced the magnitude and direction of depth differences in DOC, CDOM, and FDOM observed under stratified conditions (Tables 2 and 4, Fig. 5). Compared to pool bottom waters, surface waters had significantly lower CDOM and FDOM concentrations, higher $S_{\mathrm{R}}$, and lower FI, by 9 to $55 \%$ (Tables 2 and 4, Fig. 5). Exposure of bottom water to $\sim 12 \mathrm{~h}$ of natural sunlight resulted in a comparable loss of CDOM and FDOM, and similarly higher $S_{\mathrm{R}}$, and lower FI (11 to $27 \%$ loss or change in CDOM or FDOM compared to dark controls; Table 4). Thus, DOM in pool surface waters and in photo-exposed bottom waters had lower concentrations of aromatic DOM (i.e., CDOM and FDOM) with lower average molecular weight compared to DOM protected from UV in the bottom waters. Many studies have demonstrated that photo-degradation of

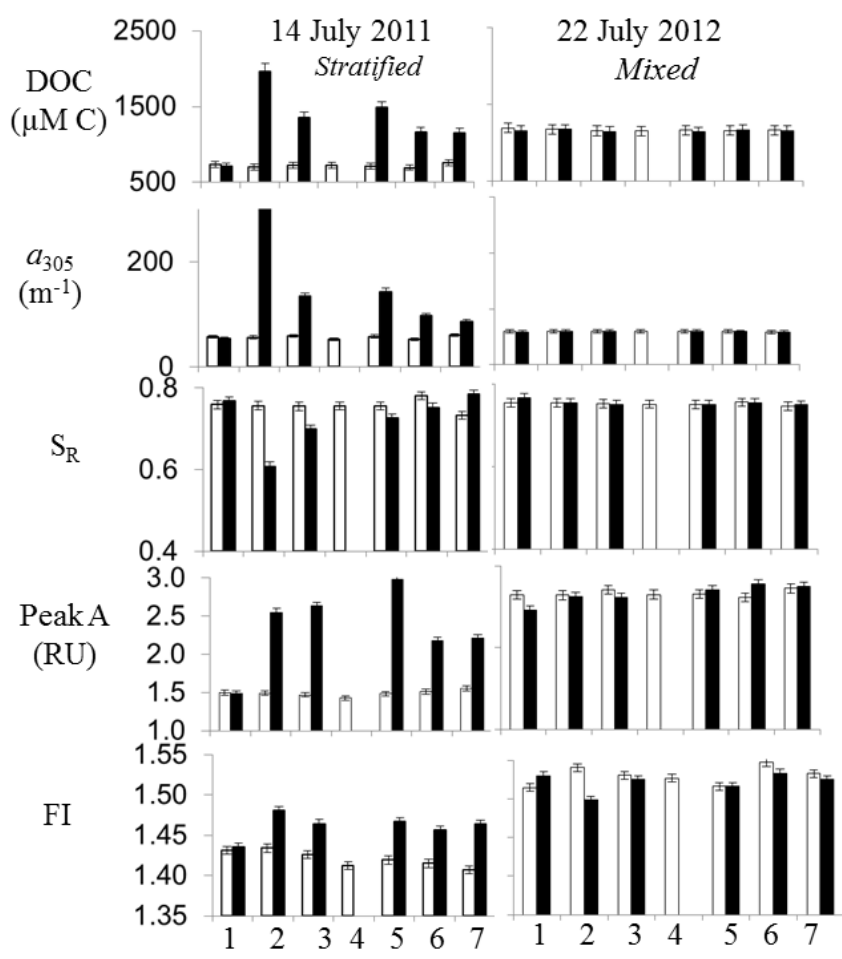

Figure 5. Concentration and quality of DOM in the surface (open bars) and bottom waters (filled bars) in pools 1-7 in Imnavait Creek under stratified (left) and mixed (right) conditions in 2011 and 2012 , respectively. CDOM and FDOM concentrations shown as absorption coefficients at $305 \mathrm{~nm}\left(a_{305}\right)$ and emission intensities at Peak A (Raman Units; RU), respectively. DOM quality shown as slope ratio $\left(S_{\mathrm{R}}\right)$ and fluorescence index $(\mathrm{FI})$; CDOM and FDOM proxies for DOM described in text.

DOM results in a loss of CDOM and FDOM (Granéli et al., 1996), a decrease in aromaticity (Brooks et al., 2007; Stubbins et al., 2010), and a decrease in average molecular weight (e.g., $S_{\mathrm{R}}$, Cory et al., 2007; Helms et al., 2008; Spencer et al., 2010), just as we observed.

It is unlikely that bacterial processing of DOM could produce similar changes to those observed between surface and bottom waters or to the results of photo-degradation experiments. Bacteria degrade stream DOM and decrease CDOM and FDOM (Cory and Kaplan, 2012), but, at the same time some bacterial processes can regenerate CDOM and FDOM (e.g., Amado et al., 2006; Moran et al., 2000), leading to a net balance between degradation and regeneration. In our experiments the dark bacterial degradation of DOM resulted in a net loss of CDOM and FDOM, but the loss was much lower compared to photo-degradation (e.g., $\sim 2$ to $8 \%$ decrease over 6 days, Table 4). Furthermore, bacterial degradation had no detectable effect on the $S_{\mathrm{R}}$ or FI, and thus cannot explain the significant differences in $S_{\mathrm{R}}$ and FI between surface and bottom waters in Imnavait Creek (Tables 2, 3 and 4, Fig. 5). 
In an earlier study of Imnavait Creek, Merck et al. (2012) found that soil water FDOM was chemically similar to pool bottom water FDOM. Cold soil water from subsurface lateral flows plunged into the pool bottom during stratified conditions, bringing in FDOM that remained relatively unchanged in composition from the FDOM in soil waters. In our study we show that, similarly, FDOM but also $\mathrm{pH}$, conductivity, DOC, and CDOM are comparable in quantity or quality between soil waters and pool bottom waters (Tables 2 and 3). These results suggest that either DOM in soil waters draining into isolated pool bottoms experiences little degradation in the pool, as would be expected based on relatively slow rates of bacterial respiration in cold, acidic, low nutrient, and often anoxic water (Table 4, Fig. 3-4), or that the pathways, rates, and fate of DOM degradation in both soils and bottom waters are similar.

\subsection{Synthesis of factors controlling DOM degradation}

Given that photochemical processes dominate the degradation and alteration of DOM in Imnavait Creek, estimates of DOM degradation or export at a stream reach or whole catchment scale must be based on an integration of the photochemical and hydrological controls on DOM degradation. These controls include (1) the amount of surface UV available to be absorbed by $\operatorname{CDOM}\left(Q_{\mathrm{dso}, \lambda}\right.$, Eq. 3$)$, (2) the amount of CDOM to absorb and attenuate UV light in the water column ( $a_{\mathrm{CDOM}, \lambda}$ and $K_{\mathrm{d}}$; Eq. 3 ), (3) the lability of DOM to photo-degradation, quantified as apparent quantum yields ( $\Phi_{\lambda}$; Eq. 3), and (4) the residence time of DOM in the water column or in a stream reach as affected by flow rates and stratification that in turn control the total UV light exposure and amount of DOM photo-degradation. These main controls and their feedbacks are summarized in Fig. 6, which shows that as light exposure increases, DOM photo-degradation increases. Similarly, there are different pathways through which increased CDOM can affect light exposure. First, higher CDOM increases light attenuation and thus helps facilitate thermal stratification. Stratification in turn results in increased water residence times that can increase the opportunity for light exposure and photo-degradation. For example, in pool surface waters where light exposure is greatest, during the day under low-flow conditions nearly the entire upper layer is stratified (Fig. 3), which increases residence time and light exposure (right side of Fig. 6). Second, although increasing CDOM increases light attenuation, the effect on light exposure can vary (left side of Fig. 6). In general, if $K_{\mathrm{d}}$ is relatively low and light penetrates to the bottom of the water column, increasing CDOM will result in greater total light exposure of DOM in the system, and thus greater total light absorption by CDOM to drive photochemical reactions. However, if $K_{\mathrm{d}}$ is relatively high and light is extinguished well before it reaches the bottom of the water column, the system is light-limited and adding more CDOM will not increase the overall light exposure of DOM (or light

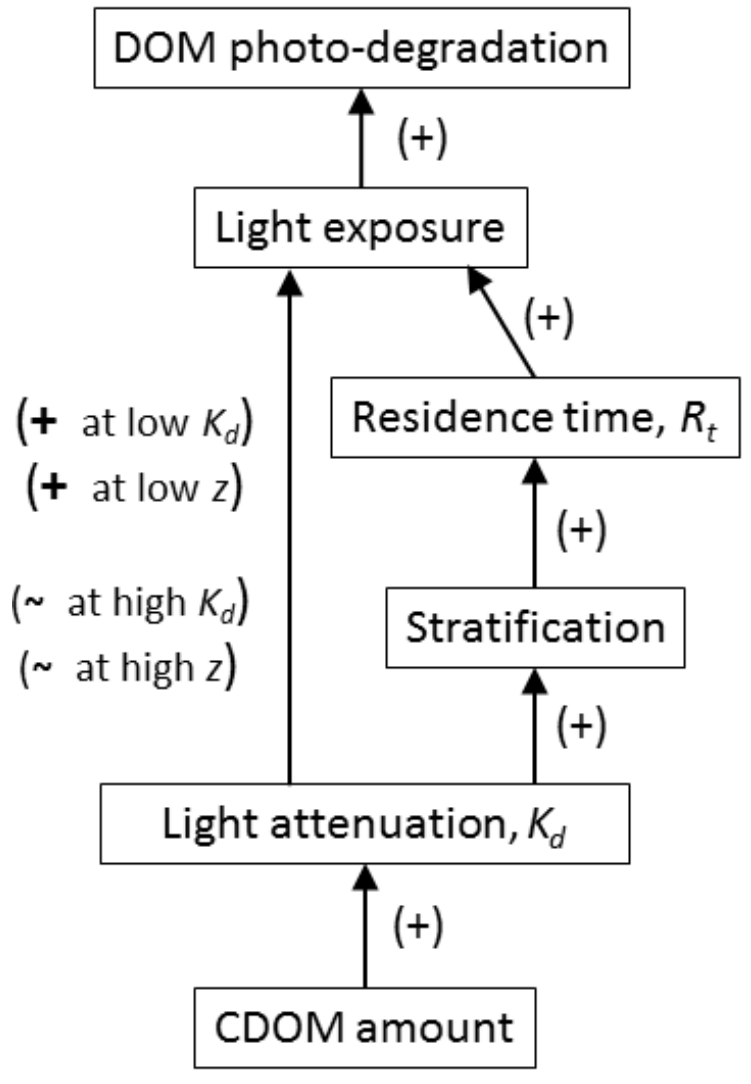

Figure 6. Conceptual diagram illustrating the controls on DOM photo-degradation. As CDOM increases it absorbs more light at the surface and strengthens stratification, which increases residence times, length of light exposure, and thus DOC photo-degradation (right side). Similarly, as CDOM and thus light attenuation increase the total amount of light exposure and light absorption increases in situations where there is low $K_{\mathrm{d}}$ or shallow water column depth $z$. However, as $K_{\mathrm{d}}$ or shallow water column depth increase the system becomes light-limited, and further increases in CDOM result in no change in DOM photo-degradation (asymptote of Fig. S1).

absorption by CDOM). The relative importance of these scenarios can be estimated by first examining the sensitivity of various components in the photo-degradation model (Eq. 3).

To investigate the sensitivity of DOM photo-degradation to the amount of surface UV, CDOM, or $\Phi_{\lambda}$, we varied each term independently in the equation for the water column rate of DOM photo-mineralization (Eq. 3), using the average, minimum, and maximum values observed in Imnavait Creek (Fig. S2). Holding surface UV and $\Phi_{\lambda}$ constant (using the average observed values) and varying CDOM across the range observed in the pool surface waters of Imnavait Creek ( 39 to $63 \mathrm{~m}^{-1}$ at $305 \mathrm{~nm}$, mean of $53 \pm 2$; Table 2), there was little variation in water column rates of photo-mineralization (Fig. 7). This result indicates that photo-degradation of DOM in Imnavait Creek is represented by higher $K_{\mathrm{d}}$ and falls in the asymptotic range shown in Fig. S1, meaning it is limited by insufficient UV light. It follows that increasing UV 


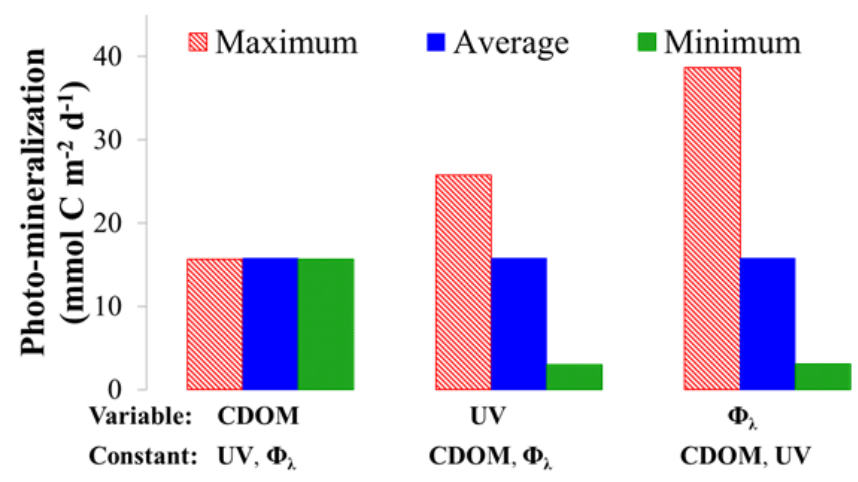

Figure 7. Effect of CDOM, incident UV, and $\Phi_{\lambda}$ (apparent quantum yield) on water column rates of photo-mineralization of DOM to $\mathrm{CO}_{2}$ in Imnavait Creek. For each scenario, two variables from Eq. 3 were held constant, and one was varied using the average, minimum, and maximum values observed over the study period at Imnavait Creek (2011-2012). UV= daily total UV reaching water surface at Imnavait Creek (dependent on solar zenith angle and cloud cover).

light (while holding CDOM and $\Phi_{\lambda}$ constant) should significantly increase the rate of DOM photo-mineralization, as shown in Fig. 7. That is, the daily total surface UV light varied by nearly 10 -fold over the course of the summer season due to differences in solar zenith angle or cloud cover (as shown for 2012 in Fig. S3), and thus there was a nearly 10 -fold higher rate of photo-mineralization when using the maximum vs. minimum surface UV light available in Eq. 3 (Fig. 7). The greatest effect on the rate of photo-degradation occurred when holding the UV light and CDOM to their average values, and varying the lability of DOM to photomineralization (i.e., varying $\Phi_{\lambda}$ ). In this case, with a 6 to 20fold range in $\Phi_{\lambda}$ (depending on wavelength; Fig. S2), DOM was converted to $\mathrm{CO}_{2}$ by sunlight $\sim 13$-fold faster using the maximum vs. the minimum observed $\Phi_{\lambda}$ (Fig. 7).

The second step in understanding photo-degradation for any system is to consider the integrated effects of light attenuation with flow rates, stratification, and anticipated residence time distributions. Integrating the photochemical and hydrological factors produces a continuum of conditions that can represent or classify any particular system (Fig. 8a, b). For example, as light exposure and residence times increase, the amount of DOM lost through photo-mineralization increases (Fig. 8a). However, the quantity and photo-lability (quality, $\Phi_{\lambda}$ ) of CDOM both determine the rates and the total amount of DOM photo-degradation. In systems with high CDOM concentrations or low light exposure, photochemical processes can be light-limited rather than substrate (CDOM) limited. In such systems waters are rarely photo-bleached clear before inputs from soil waters or sediments replenish the CDOM lost to photo-degradation. This is the situation in Imnavait Creek (e.g., Table 3; Fig. 8a, left side;), which applies to most arctic headwater catchments or any system that receives high inputs of organic matter (Koehler et al., 2014). Similarly, if the photo-lability (and thus the $\Phi_{\lambda}$ ) of the DOM is low (the lower, dashed line on Fig. 8a), then more UV is required for photo-degradation, and the system would be again considered light-limited. This is likely the case in the lowerCDOM Kuparuk River (spectral characteristics described in Cory et al., 2014), a fourth-order stream where it is joined by Imnavait Creek, although under some situations this river may be co-limited by light and substrate. Most of the waters in the Alaskan Arctic would fall in between these examples on this conceptual diagram, based on CDOM concentrations and $\Phi_{\lambda}$ values (Cory et al., 2014). In these cases where DOM photo-degradation is light-limited, the amount of time the DOM is exposed to UV becomes more important than the mass of DOM exposed. On the other hand, if photo-lability is very high and CDOM concentrations are very low, then the system is substrate-limited and the total mass of DOM exposed is more important than the amount of time the DOM spends exposed to UV (Fig. 8a, right side). This is because when the system is substrate-limited, even a short exposure to UV will result in rapid and substantial photo-degradation, and exposing greater amounts of DOM even over short residence times will increase the overall photochemical processing in the system. Similarly, as one moves further right on Fig. 8a, the DOM loss as a percentage of initial amount declines once the system has switched from light- to substratelimitation.

Finally, the nature and controls on DOM photodegradation of a river reach (or whole system) can be expressed as a function of light attenuation and residence times (Fig. 8b). When water is flowing quickly through a stream the residence times are very short and the water column is well mixed, DOM spends less time exposed to UV light, and even at medium to low values of CDOM and $K_{\mathrm{d}}$ the system is light-limited (Fig. 8a,b left) and DOM loss to photomineralization is low (Fig. 8a left). At the other extreme, low flow conditions create long residence times, and even at medium values of CDOM the system is substrate-limited (Fig. 8b, right) and again DOM photo-mineralization may become low (Fig. 8a, right).

The relationship between residence time and DOM photodegradation in Imnavait Creek was explored by multiplying Eq. (3) (representing the water column rate of DOM photodegradation as the product of UV light, $\mathrm{CDOM}$, and $\Phi_{\lambda}$ ) by residence time to generate the results in Fig. 9. Combinations of minimum and maximum values of incident UV light, CDOM, and $\Phi_{\lambda}$ were used to create a "lowest case" and "highest case" scenario of photo-degradation over a range of residence times from hours to 20 days. Thus, Fig. 9 shows cumulative DOM loss as a function of residence time for a range of conditions (i.e., UV light availability, CDOM, and $\Phi_{\lambda}$ ) generated using a "lowest case" and "highest case" scenario of photo-degradation. Because it was shown in Fig. 7 (left set of bars) that the natural variability in CDOM concentrations has no effect on water column rates of photo- 


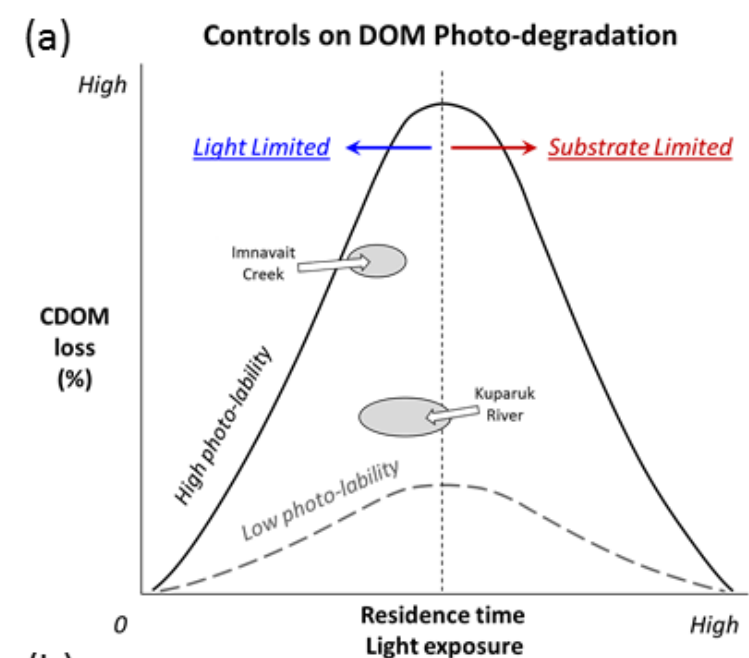

(b)

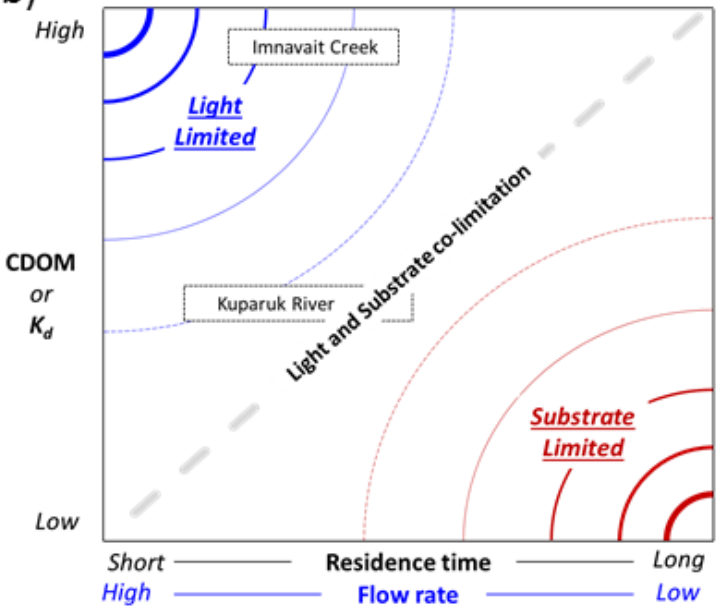

Figure 8. Controls on DOC photo-degradation. (a) As residence time or light exposure increase, so does DOC photo-degradation (\% loss of the initial pool of CDOM, without replacement). The CDOM loss for any given light exposure is greater for higher photo-labile DOC (solid line) than it is for lower photo-labile DOC (dashed line). At low light exposure levels photo-degradation is "lightlimited", but after sufficient CDOM is lost the process switches to be "substrate-limited" (insufficient CDOM). (b) This shows the light- vs. substrate- limitation in terms of CDOM concentrations or light attenuation $\left(K_{\mathrm{d}}\right), y$ axis, and the water residence time or flow rate ( $x$ axis). At high CDOM and short residence time there is insufficient light available for photo-degradation (upper left), while at low CDOM concentrations and long residence times there is abundant light yet insufficient CDOM. The range of conditions for DOC photo-degradation in Imnavait Creek is likely always light-limited, while in the Kuparuk River conditions may be substrate-limited at times.

degradation, the scenarios were created by varying incoming UV light and DOM quality $\left(\Phi_{\lambda}\right)$. For example, the minimum UV light and minimum $\Phi_{\lambda}$ values observed resulted in low rates of photo-mineralization; over a 20 -day residence time less than $5 \%$ of the DOM in surface waters could be converted to $\mathrm{CO}_{2}$ by photo-mineralization. Conversely, combin-

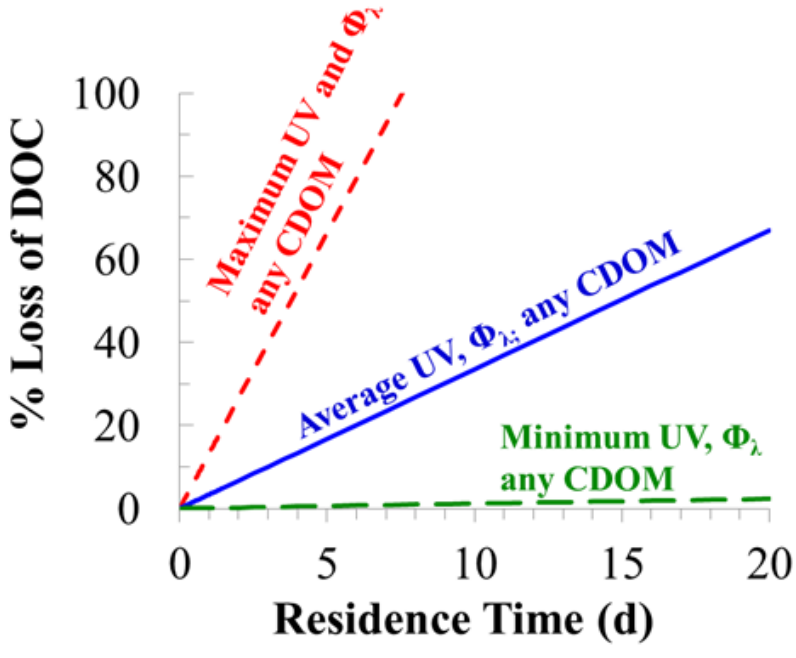

Figure 9. Cumulative percent of DOC loss in Imnavait Creek lost through photo-mineralization as calculated from Eq. 3 (removal of DOC as mol $\mathrm{C} \mathrm{m}^{-2} \mathrm{~d}^{-1}$ over the mean depth in Imnavait Creek; $0.5 \mathrm{~m}$ ) in Imnavait Creek using combinations of the range of surface UV light exposure, CDOM concentrations, and apparent quantum yields $\left(\Phi_{\lambda}\right)$ measured in this study for up to a 20-day residence time. For each scenario, the initial DOC concentration was set to $943 \mu \mathrm{M} \mathrm{C}$, the average surface water DOC concentration over both 2011 and 2012 (Table 2). Calculations do not include (1) the effect of DOC loss on changing light attenuation $\left(K_{\mathrm{d}}\right)$ over the residence time (i.e., CDOM and thus $K_{\mathrm{d}, \lambda}$ remain constant over the residence time for each scenario), or (2) the effect of UV light exposure on $\Phi_{\lambda}$ over time ( $\Phi_{\lambda}$, or DOM lability, remained constant over the residence time for each scenario).

ing the maximum UV light and maximum $\Phi_{\lambda}$ values shows that $100 \%$ of the DOM could be converted to $\mathrm{CO}_{2}$ by photomineralization at the end of about 1 week (Fig. 9). However, a precise estimate of residence time is difficult to achieve in practice given that there are inputs of water and "fresh" (labile) CDOM as a parcel of water moves downstream; accounting for these inputs is needed to quantify the total, integrated amount of DOM broken down by light as a function of residence time in a stream.

In all surface waters there is a variety of combinations of photochemical and hydrological controls that vary in space and time, and that define the "range" of DOM photodegradation rates. For example, in Imnavait Creek longer residence times occur during times of low flow and stratification, and this stratification serves to protect DOM from UV light by isolating water masses in pool bottoms (e.g., Table 3, Fig. 5). The volume of water sequestered in the pool bottoms (below the mixing depth) under stratified conditions was on average about $70 \%$ of the total pool volume (Figs. 3, 4; Merck et al. 2012). Thus, under stratified conditions, the majority of the pool volume was sequestered in the bottom, below the depth of UV light penetration $(8-45 \mathrm{~cm}$ see results Sect. 3.2). However, the depth of light penetration 
into the ponds does not differ between stratified (low flow) or mixed (high flow) conditions as shown by the limited differences in $a_{\mathrm{CDOM} \lambda}$ values at $305 \mathrm{~nm}$ between these conditions in Imnavait Creek (comparing pool surface $a_{\mathrm{CDOM} \lambda}$ values in 2011 vs. 2012, Table 3). Thus, the amount of CDOM exposed to light, or the rate of light absorption, does not differ between stratified vs. mixed conditions (for a given amount of sunlight under given sky conditions). The only difference is the amount of time for the photo-degradation to occur (greater photo-degradation under longer residence times associated with low-flow, stratified conditions; Fig. 9). Therefore, although most water was sequestered in the pool bottoms under stratified conditions, more DOM is lost due to photo-degradation under these conditions. This is because there is enough light-absorbing DOM that is labile to photodegradation even in the pool surface waters under all conditions that DOM photo-degradation is not limited by substrate (DOM supply). The amount of water and DOM sequestered in the bottom waters does not influence the amount of DOM that can be degraded by light in this system.

Rates of photo-mineralization varied little over the narrow range of CDOM observed in the surface waters of Imnavait Creek (Fig. 7, left), and because CDOM was very high photochemical reactions were light-limited (Fig. 8b). In addition, the consistently high CDOM concentrations observed across space (pool to pool) and averaged over time (2011 to 2012) in Imnavait Creek (Tables 2 and 3, Fig. 5) suggests that CDOM lost to photo-mineralization under any photochemical or hydrological conditions is rapidly replenished from riparian soil waters over relatively short time periods (see also Merck et al., 2012). It is likely that stream reaches with high CDOM concentrations (substrate rich) and residence times in the range observed in Imnavait Creek are similarly always lightlimited (Fig. 8). Increased residence times, or lower CDOM concentrations such as those observed in the Kuparuk River (Page et al., 2014), will move a system from light-limitation toward co-limitation by light and substrate (Fig. 8), again depending on the combination of photochemical and hydrological properties and their variability in space and time.

\section{Conclusions}

Results from this study demonstrate that in Imnavait Creek photo-degradation dominates over bacterial degradation of DOM, and photo-degradation can create substantial differences in DOM chemistry between water masses isolated during stratification. The amount and lability of CDOM and the light attenuation by CDOM form a critical control point in DOM degradation - higher CDOM attenuates light faster with depth but results in no change or an increase in the overall rate of light absorption in the water column. With increasing CDOM and thus increasing rates of light-absorption, photo-degradation rates in the water column are more likely to be light-limited and rates will increase with incident UV light or residence time. Given that higher light attenuation by CDOM traps heat in surface waters and creates stratification, which lengthens residence times and thus the timeintegrated light exposure of DOM, low-flow conditions in Imnavait Creek likely maximize the conditions for photodegradation of DOM.

On the other hand, if CDOM concentrations are very low, then the system is substrate-limited and the total mass of DOM exposed is more important than the amount of time the DOM spends exposed to UV (Fig. 8a, right side). This is because when the system is substrate-limited, even a short exposure to UV will result in rapid and substantial photodegradation, and exposing greater amounts of DOM even over short residence times will increase the overall photochemical processing in the system. In addition, in our conceptual model the lability of DOM to photo-degradation acts as a control on processing rates independent of whether a system is light- or substrate-limited (Fig. 8a). Finally, at the scale of a stream reach or catchment, the balance between light- vs. substrate-limitation of DOM degradation varies with changes in water residence times, the incident UV light, and photo-lability of DOM. Our analyses indicate that the hydrological and photochemical conditions in Imnavait Creek create light-limitation for DOM photo-degradation, and we suggest that photo-degradation in most streams and ponds with high CDOM is similarly light-limited.

\section{The Supplement related to this article is available online at doi:10.5194/bg-12-6669-2015-supplement.}

Author contributions. G. W. Kling, B. T. Neilson and R. M. Cory designed the field sampling plan and all authors contributed to the field work and data analysis. RMC, GWK and BTN prepared the manuscript with contributions $\mathrm{KHH}$.

Acknowledgements. Funding was provided in part by grants NSF ARC-1204220 (to BTN), NSF DEB-1026843 (to GWK), NSF OPP-1022876/1023270 (to RMC and GWK), and NSF - CAREER 1255060 (to RMC). We thank Jason Dobkowski, Brittany Papworth, Sara Fortin, and EDC staff at Toolik Field Station for help in the field.

Edited by: W. F. Vincent

\section{References}

Amado, A. M., Farjalla, V. F., Esteves, F. D. A., Bozelli, R. L., Roland, F., and Enrich-Prast, A.: Complementary pathways of dissolved organic carbon removal pathways in clear-water Amazonian ecosystems: Photochemical degradation and bacterial uptake, FEMS Microbiol. Ecol., 56, 8-17, 2006. 
Battin, T. J., Kaplan, L. a., Findlay, S., Hopkinson, C. S., Marti, E., Packman, A. I., Newbold, J. D., and Sabater, F.: Biophysical controls on organic carbon fluxes in fluvial networks, Nat. Geosci., 2, 595-595, 2009.

Boano, F., Harvey, J. W., Marion, A., Packman, A. I., Revelli, R., Ridolfi, L., and Wörman, A.: Hyporheic flow and transport processes:Mechanisms,models, and biogeochemical implications, Rev. Geophys., 52, 603-679, doi:10.1002/2012RG000417, 2014.

Brooks, M. L., Meyer, J. S., and McKnight, D. M.: Photooxidation of wetland and riverine dissolved organic matter: Altered copper complexation and organic composition, Hydrobiologia, 579, 95113, 2007.

Caplanne, S. and Laurion, I.: Effect of chromophoric dissolved organic matter on epilimnetic stratification in lakes, Aquat. Sci., 70, 123-133, 2008.

Chapra, S. C. and Runkel, R. L.: Modeling Impact of Storage Zones on Stream Dissolved Oxygen, J. Environ. Eng., 125, 415-419, 1999.

Cole, J. J., Caraco, N. F., Kling, G. W., and Kratz, T. K.: Carbon dioxide supersaturation in the surface waters of lakes, Science, 265, 1568-1570, 1994.

Cole, J. J., Prairie, Y. T., Caraco, N. F., McDowell, W. H., Tranvik, L. J., Striegl, R. G., Duarte, C. M., Kortelainen, P., Downing, J. A., Middelburg, J. J., and Melack, J.: Plumbing the global carbon cycle: Integrating inland waters into the terrestrial carbon budget, Ecosystems, 10, 171-184, 2007.

Cory, R. M. and Kaplan, L. A.: Biological lability of streamwater fluorescent dissolved organic matter, Limnol. Oceanogr., 57, 1347-1360, 2012.

Cory, R. M., McKnight, D. M., Chin, Y. P., Miller, P., and Jaros, C. L.: Chemical characteristics of fulvic acids from Arctic surface waters: Microbial contributions and photochemical transformations, J. Geophys. Res.-Biogeosci., 112, G04S51, doi:10.1029/2006JG000343, 2007.

Cory, R. M., Miller, M. P., McKnight, D. M., Guerard, J. J., and Miller, P. L.: Effect of instrument-specific response on the analysis of fulvic acid fluorescence spectra, Limnol. Oceanogr. Methods, 8, 67-78, 2010.

Cory, R. M., Crump, B. C., Dobkowski, J. A., and Kling, G. W.: Surface exposure to sunlight stimulates $\mathrm{CO}_{2}$ release from permafrost soil carbon in the Arctic, Proc. Natl. Acad. Sci. USA, 110, 3429-34, 2013.

Cory, R. M., Ward, C. P., Crump, B. C., and Kling, G. W.: Sunlight controls water column processing of carbon in arctic fresh waters, Science, 345, 925-928, 2014.

Detterman, R. L., Bowsher, A. L., and Dutro Jr., J. T.: Glaciation on the Arctic Slope of the Brooks Range, Northern Alaska, Arctic, 11, 43-61, 1958.

Fee, E. J., Hecky, R. E., Kasian, S. E. M., and Cruikshank, D. R.: Effects of lake size, water clarity, and climatic variability on mixing depths in Canadian Shield lakes, Limnol. Oceanogr., 41, 912920, 1996

Gareis, J. a L., Lesack, L. F. W., and Bothwell, M. L.: Attenuation of in situ UV radiation in Mackenzie Delta lakes with varying dissolved organic matter compositions, Water Resour. Res., 46, $1-14,2010$.

Hamilton, T. D.: Late Cenozoic glaciation of the central Brooks Range, in: Glaciation in Alaska-The geologic record, edited by:
Hamilton, T. D., Reed, K. M., and Thorson, R. M., Alaska Geological Society, 9-50, 1986.

Helms, J. R., Stubbins, A., Ritchie, J. D., Minor, E. C., Kieber, D. J., and Mopper, K.: Absorption spectral slopes and slope ratios as indicators of molecular weight, source, and photobleaching of chromophoric dissolved organic matter, Limnol. Oceanogr., 53, 955-969, 2008.

Hinzman, L. D., Kane, D. L., Gieck, R. E., and Everett, K. R.: Hydrologic and thermal properties of the active layer in the Alaskan Arctic, Cold Reg. Sci. Technol., 19, 95-110, 1991.

Hobbie, J. E.: Limnology of Tundra Ponds, Barrows, Alaska, US/IBP Synth. Ser. no. 13 Dowden, Hutchinson Ross, Inc. Strodsbeng, NULL, 514 pp., 1980.

Houser, J. N.: Water color affects the stratification, surface temperature, heat content, and mean epilimnetic irradiance of small lakes, Can. J. Fish. Aquat. Sci., 63, 2447-2455, 2006.

Hu, C. M., Muller-Karger, F. E., and Zepp, R. G.: Absorbance, absorption coefficient, and apparent quantum yield: A comment on common ambiguity in the use of these optical concepts, Limnol. Oceanogr., 47, 1261-1267, 2002.

Judd, K., Crump, B., and Kling, G.: Bacterial responses in activity and community composition to photo-oxidation of dissolved organic matter from soil and surface waters, Aquat. Sci.-Res. Across Boundaries, 69, 96-107, 2007.

Kane, D. L., Youcha, E. K., Stuefer, S. L., Myerchin-Tape, G., Lamb, E., Homan, J. W., Gieck, R. E., Schnabel, W. E., and Toniolo, H.: Hydrology and Meteorology of the Central Alaskan Arctic: Data Collection and Analysis, Final Report, University of Alaska Fairbanks, Water and Environmental Research Center, Report INE/WERC 14.05, Fairbanks, Alaska, 2014.

Kane, D. L. and Hinzman, L. D.: Climate data from the North Slope Hydrology Research project, available from: http://ine.uaf.edu/ werc/projects/NorthSlope (last access: February 2013), 2011.

Kane, D. L., Hinzman, L. D., McNamara, J. P., Zhang, Z., and Benson, C. S.: An overview of a nested watershed study in Arctic Alaska, Nord. Hydrol., 31, 245-266, 2000.

Kane, D. L., Gieck, R. E., Kitover, D. C., Hinzman, L. D., McNamara, J. P., and Yang, D.: Hydrological cycle on the North Slope of Alaska, in: Northern Research Basins Water Balance, edited by: Kane, D. L. and Yang, D., 224-236, IAHS Press, Wallingford, 2004.

Kling, G. W.: Comparative transparency, depth of mixing, and stability of stratification in lakes of Cameroon, West Africa, Limnol. Oceanogr., 33, 27-40, 1988.

Kling, G. W., Kipphut, G. W., and Miller, M. C.: Arctic lakes and streams as gas conduits to the atmosphere: implications for tundra carbon budgets, Science, 251, 298-301, 1991.

Koehler, B., Landelius, T., Weyhenmeyer, G. A., Machida, N., and Tranvik, L. J.: Sunlight-induced carbon dioxide emissions from inland waters, Global Biogeochem. Cy., 28, 696-711, 2014.

McKnight, D. M., Boyer, E. W., Westerhoff, P. K., Doran, P. T., Kulbe, T., and Andersen, D. T.: Spectrofluorometric characterization of dissolved organic matter for indication of precursor organic material and aromaticity, Limnol. Oceanogr., 46, 38-48, 2001.

McNamara, J. P., Kane, D. L., and Hinzman, L. D.: An analysis of streamflow hydrology in the Kuparuk River Basin, Arctic Alaska: a nested watershed approach, J. Hydrol., 206, 39-57, 1998. 
McNamara, J. P., Kane, D. L., Hobbie, J. E., and Kling, G. W.: Hydrologic and biogeochemical controls on the spatial and temporal patterns of nitrogen and phosphorus in the Kuparuk River, arctic Alaska, Hydrol. Process., 22, 3294-3309, 2008.

Merck, M. F. and Neilson, B. T.: Modelling in-pool temperature variability in a beaded arctic stream, Hydrol. Process., 26, 39213933, 2012.

Merck, M. F., Neilson, B. T., Cory, R. M., and Kling, G. W.: Variability of in-stream and riparian storage in a beaded arctic stream, Hydrol. Process., 26, 2938-2950, 2012.

Miller, M. P., McKnight, D. M., Chapra, S. C., and Williams, M. $\mathrm{W} .:$ A model of degradation and production of three pools of dissolved organic matter in an alpine lake, Limnol. Oceanogr., 54, 2213-2227, 2009.

Miller, W. L.: Effects of UV-radiation on aquatic humus: photochemical principles and experimental considerations, in: Aquatic Humic Substnaces - Ecology and Biogeochemistry, edited by: Hesson, D. O. and Tranvik, L. J., Springer Berlin Heidelberg, 126-143, 1998.

Moran, M. A., Sheldon, W. M., and Zepp, R. G.: Carbon loss and optical property changes during long-term photochemical and biological degradation of estuarine dissolved organic matter, Limnol. Oceanogr., 45, 1254-1264, 2000.

Morris, D. P., Zagarese, H., Willliamson, C., Balseiro, E. G., Hargreaves, B. R., Modenutti, B., Moeller, R., and Queimalinos, C.: The attenuation of solar UV radiation in lakes and the role of dissolved organic carbon, Limnol. Oceanogr., 40, 1381-1391, 1995.

Neilson, B. T., Hatch, C. E., Ban, H., and Tyler, S. W.: Solar radiative heating of fiber-optic cables used to monitor temperatures in water, Water Resour. Res., 46, W08540, doi:10.1029/2009WR008354, 2010.

Osterkamp, T. E. and Payne, M. W.: Estimates of permafrost thickness from well logs in northern Alaska, Cold Reg. Sci. Technol., 5, 13-27, 1981 .

Page, S. E., Logan, J. R., Cory, R. M., and McNeill, K.: Evidence for dissolved organic matter as the primary source and sink of photochemically produced hydroxyl radical in arctic surface waters, Environ. Sci. Process. Impacts, 16, 807-822, 2014.

Prairie, Y., Breton, J., Vallières, C., and Laurion, I.: Limnological properties of permafrost thaw ponds in northeastern Canada, Can. J. Fish. Aquat. Sci., 66, 1635-1648, 2009.

Spencer, R. G. M., Hernes, P. J., Ruf, R., Baker, A., Dyda, R. Y., Stubbins, A., and Six, J.: Temporal controls on dissolved organic matter and lignin biogeochemistry in a pristine tropical river, Democratic Republic of Congo, J. Geophys. Res.-Biogeosci., 115, G03013, doi:10.1029/2009JG001180, 2010.
Stedmon, C. A., Markager, S., and Bro, R.: Tracing dissolved organic matter in aquatic environments using a new approach to fluorescence spectroscopy, Mar. Chem., 82, 239-254, 2003.

Stubbins, A., Spencer, R. G. M., Chen, H., Hatcher, P. G., Mopper, K., Hernes, P. J., Mwamba, V. L., Mangangu, A. M., Wabakanghanzi, J. N., and Six, J.: Illuminated darkness: Molecular signatures of Congo River dissolved organic matter and its photochemical alteration as revealed by ultrahigh precision mass spectrometry, Limnol. Oceanogr., 55, 1467-1477, 2010.

Tranvik, L. J. and Bertilsson, S.: Contrasting effects of solar UV radiation on dissolved organic sources for bacterial growth, Ecol. Lett., 4, 458-463, 2001.

Vähätalo, A. V. and Wetzel, R. G.: Long-term photochemical and microbial decomposition of wetland-derived dissolved organic matter with alteration of ${ }^{13} \mathrm{C}:{ }^{12} \mathrm{C}$ mass ratio, Limnol. Oceanogr., 53, 1387-1392, 2008.

Walker, D. A., Binnian, E., Evans, B. M., Lederer, N. D., Nordstrand, E., and Webber, P. J.: Terrain, vegetation and landscape evolution of the R4D research site, Brooks-Range-foothills, Alaska, Holarct. Ecol., 12, 238-261, 1989.

Watanabe, S., Laurion, I., Chokmani, K., Pienitz, R., and Vincent, W. F.: Optical diversity of thaw ponds in discontinuous permafrost: A model system for water color analysis, J. Geophys. Res.-Biogeosci., 116, G02003, doi:10.1029/2010JG001380, 2011.

Weishaar, J. L., Aiken, G. R., Bergamaschi, B. A., Fram, M. S., Fujii, R., and Mopper, K.: Evaluation of specific ultraviolet absorbance as an indicator of the chemical composition and reactivity of dissolved organic carbon, Environ. Sci. Technol., 37, 47024708, 2003.

Wetzel, R. G.: Lake and River Ecosystems, Limnology, 37, 490525, 2001.

Zarnetske, J. P., Haggerty, R., Wondzell, S. M., and Baker, M. A.: Dynamics of nitrate production and removal as a function of residence time in the hyporheic zone, J. Geophys. Res.-Biogeosci., 116, G01025, doi:10.1029/2010JG001356, 2011. 